See discussions, stats, and author profiles for this publication at: https://www.researchgate.net/publication/282328807

\title{
Avulsive Rivers in the Hydrology of the Pantanal Wetland
}

Chapter · June 2015

DOI: 10.1007/698_2015_351

\section{CITATIONS}

23

6 authors, including:

Mario Assine

São Paulo State University

154 PUBLICATIONS 1,923 CITATIONS

SEE PROFILE

๑

José Stevaux

Universidade Federal de Mato Grosso do Sul

89 PUBLICATIONS 514 CITATIONS

SEE PROFILE
READS

322

7. Hudson De Azevedo Macedo

Prefeitura Municipal de São Carlos

30 PUBLICATIONS 65 CITATIONS

SEE PROFILE

6.) Ivan Bergier

Brazilian Agricultural Research Corporation (EMBRAPA) 128 PUBLICATIONS 916 CITATIONS

SEE PROFILE

Some of the authors of this publication are also working on these related projects:

Quantitative approaches for big river deposits: integrated field geology and 3D photogrammetric models View project

Ostracodes da Formação Santana (Cretáceo Inferior, Aptiano superior), bacia do Araripe, NE-Brasil: taxonomia, distribuição estratigráfica e paleoecologia View project 


\title{
Avulsive Rivers in the Hydrology of the Pantanal Wetland
}

\author{
Mario Luis Assine, Hudson Azevedo Macedo, José Cândido Stevaux, \\ Ivan Bergier, Carlos Roberto Padovani, and Aguinaldo Silva
}

\begin{abstract}
This chapter presents and discusses the avulsive nature of the Pantanal rivers and shows how the ever-changing drainage network influences the surface hydrology and ecology. Besides, the systemic portrait here outlined provides new insights concerning the Pantanal hydrodynamics, in its particularities and as a whole system. A simple model of the avulsion process is illustrated, and several realistic examples of the processes leading to river avulsions are shown and discussed. The north-to-south flood-pulse wave due to the presence of bottlenecks is further described in detail. This systemic approach allows identifying that the fluvial "avulsive and bottleneck" dynamics seasonally affects both local and regional ecohydrological processes. Moreover, it shows that avulsive processes are commonplace in Pantanal, and changes in land use, particularly in river headwaters in the highlands, accelerate the avulsions, making the sustainable use of the Pantanal lowland areas difficult.
\end{abstract}

Keywords Flood dynamics, Fluvial avulsion, Fluvial bottlenecks, Fluvial megafans, Multichannel systems

M.L. Assine ( $\triangle)$, H.A. Macedo, and J.C. Stevaux

Universidade Estadual Paulista - Unesp, Instituto de Geociências e Ciências Exatas, Campus

de Rio Claro. Avenida 24A, 1515 Rio Claro 13506-900, Brazil

e-mail: assine@rc.unesp.br

I. Bergier

Laboratory of Biomass Conversion, Embrapa Pantanal, Corumbá, Brazil

C.R. Padovani

Laboratory of Geoprocessing, Embrapa Pantanal, Corumbá, Brazil

A. Silva

Department of Geography, Federal University of Mato Grosso do Sul, Corumbá, Brazil

I. Bergier and M.L. Assine (eds.), Dynamics of the Pantanal Wetland

in South America, Hdb Env Chem, DOI 10.1007/698_2015_351,

(C) Springer International Publishing Switzerland 2015 


\author{
Contents \\ 1 Introduction \\ 2 Avulsive Rivers in Distributary and Multichannel Systems \\ 3 Depositional Tract and Surface Hydrology Dynamics \\ 4 Hydraulic Bottlenecks and the Flooding Wave \\ 5 Conclusion \\ References
}

\title{
1 Introduction
}

The Pantanal wetland is located in the middle of South America in the upper portion of the La Plata Basin, where seasonal changes in rainfall largely control the annual flood pulse of river floodplains [1]. Inter-annual and inter-decadal fluctuations in intensity, duration, and magnitude of the flood pulse are modulated by global-scale phenomena as the Intertropical Convergence Zone (ITCZ) and the South Atlantic Convergence Zone (SACZ) [2-5]. The convergence of airflows into the ITCZ overrides the opposite effects of wind patterns known as easterlies [6]. Rainfall quantity and distribution are usually affected by changes in sea surface temperature [7], which in turn influences the South American Monsoon System [8, 9].

The annual movement of the overhead sun causes the ITCZ to migrate northerly and southerly throughout the year, which affects wet climates in tropical latitudes. The Subtropical Atlantic Anticyclone shifts from S30 northward in the summer and produces NE-to-NW winds which push the continental equatorial air mass toward the Upper Paraguay Basin. Because of this phenomenon, the Pantanal region has a typical wet-dry climate whose rainfall regime is the most important climatic variable $[10,11]$. Although temperature range can seasonally vary from $-1^{\circ} \mathrm{C}$ to $41^{\circ} \mathrm{C}$, the seasonal mean temperature is virtually constant and ranges between $20^{\circ} \mathrm{C}$ in July and $27^{\circ} \mathrm{C}$ in December, whereas rainfall is, in general, well marked seasonally [12, 13]. According to Garcia [10], other factors may also influence the regional climate, as the South Amazon humid air mass and the cold front of polar instability that reaches the SE and S portion of the Pantanal.

The Pantanal wetland is an immense lowland of approximately $150,000 \mathrm{~km}^{2}$ (altitudes $<200 \mathrm{~m}$ a.s.1.) located in the Upper Paraguay Basin (Fig. 1). The annual precipitation in river headwaters is not homogeneous but varies from 1,200 to $1,350 \mathrm{~mm}$ at north-northeast to 710-1,200 at the south-southwestern sector, with the lowest annual precipitation of $700 \mathrm{~mm}$ in the center of the Pantanal (Fig. 2). This precipitation/discharge dynamics largely relies on the "monsoon-like effect" produced by the altitudinal gradient between low- and highlands [14]. Also, the majority of the annual rainfall takes place from October to March, whereas July to September is the driest period [12].

This chapter provides insightful information interlinking climate, geology, and hydrology for better portraying and understanding the Pantanal dynamics in its particularities and as a whole system. 


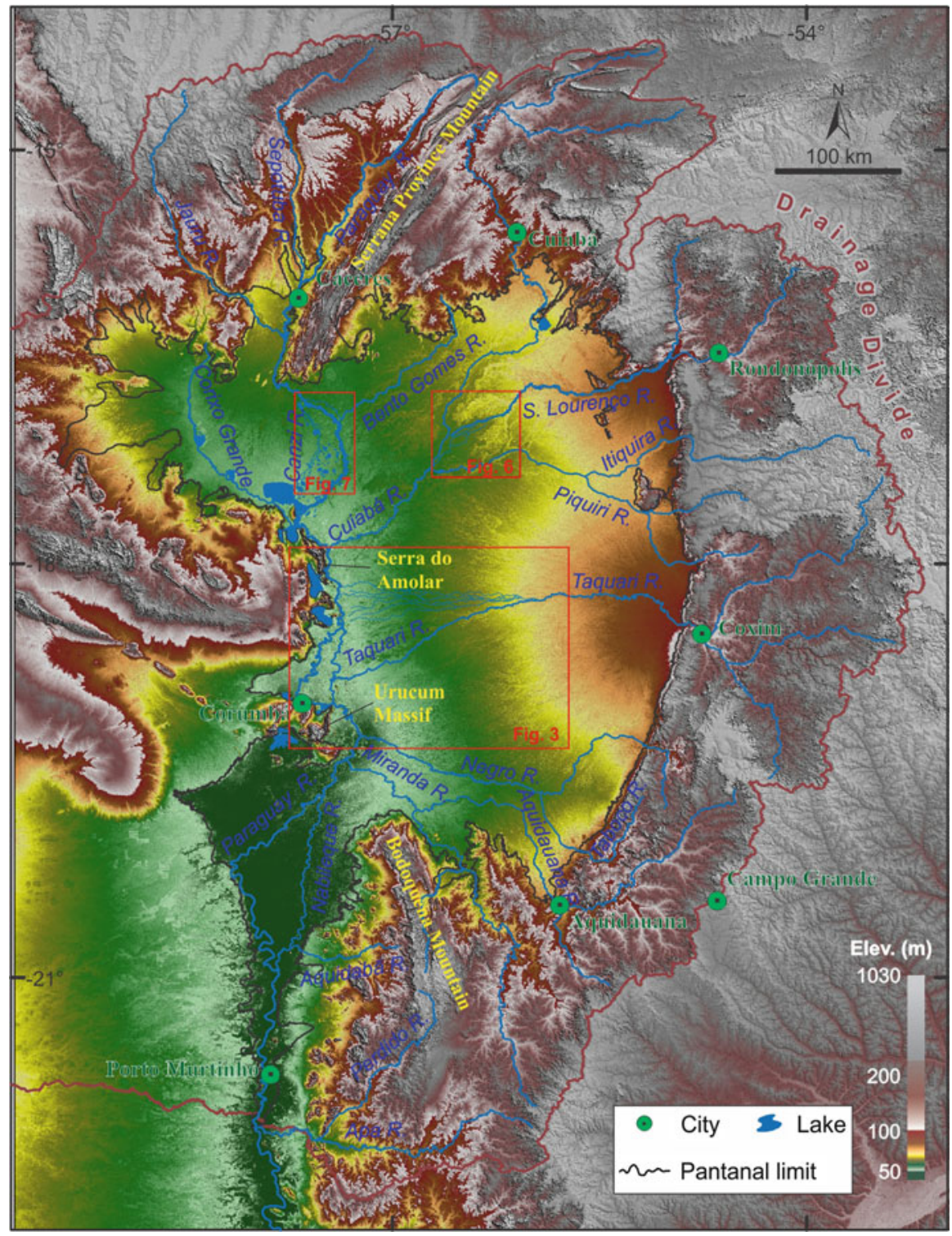

Fig. 1 Hypsometry and the drainage network of Upper Paraguay Basin, with indication of the Pantanal area (digital elevation model from Shuttle Radar Topographic Mission - SRTM) 

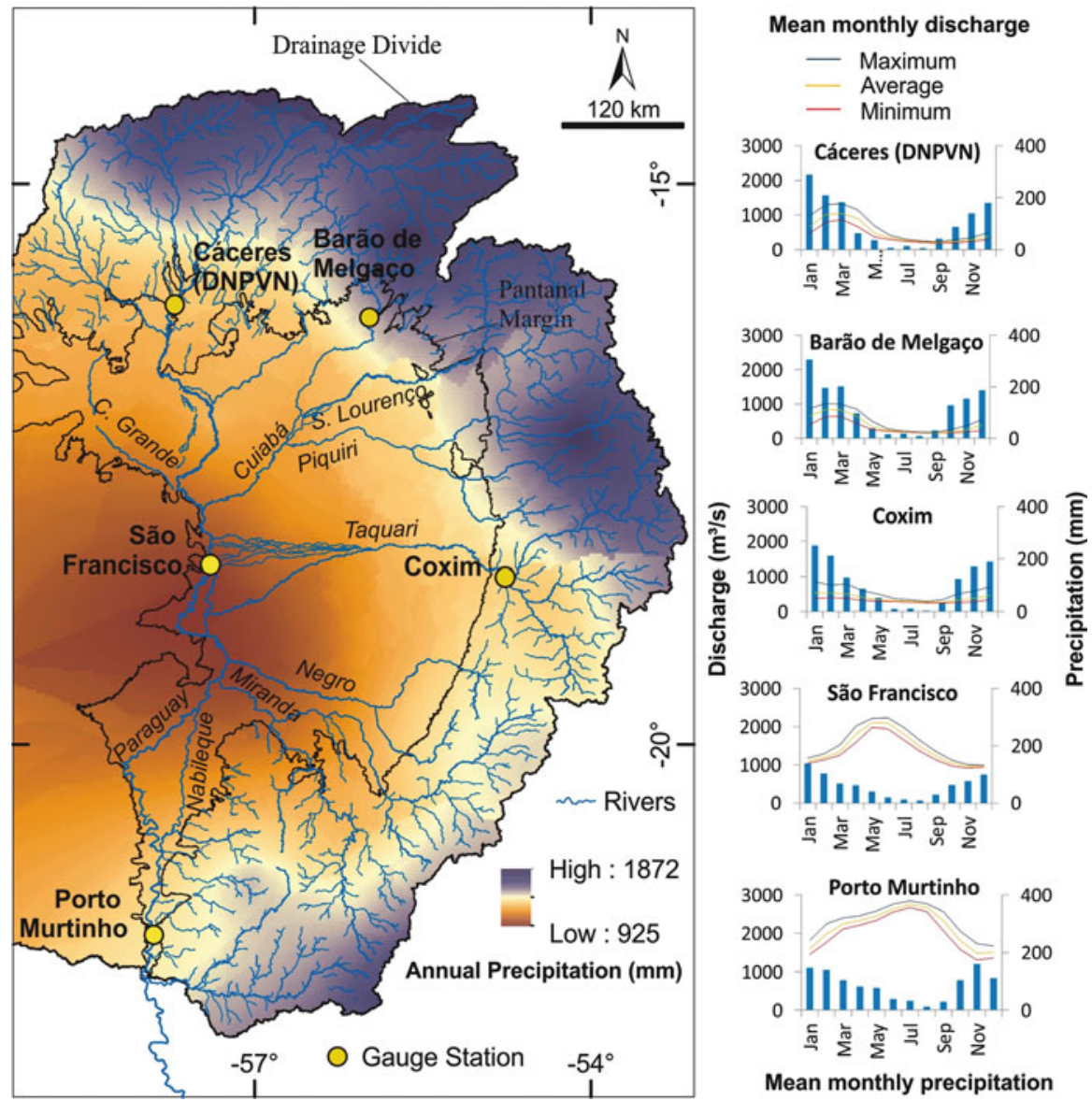

Fig. 2 Hydrographs of some rivers of the Upper Paraguay Basin (monthly mean during the period 2003-2012). The annual precipitation map was obtained by the Kriging interpolation of data in the same period (Data source: ANA - Brazilian Agency of Water)

\section{Avulsive Rivers in Distributary and Multichannel Systems}

Rivers in the catchment area surrounding the Pantanal wetland are essentially bedrock rivers, which means watercourses formed by erosion of underlying rocks with valley. Many small stream rivers flowing into a large river (main stem) compose the tributary drainage networks, such as the drainage basins of the rivers Miranda, Aquidauana, Taquari, São Lourenço, Paraguay, and Cuiabá (see Fig. 1). Incision processes carve valleys and confine the flow in thalwegs. The sediment generated by erosion is transported downstream, with little and short-lived alluvial deposition along the valley. 
The lateral slopes vanish when the confined rivers reach the Pantanal basin and the rivers develop into unconfined systems. Sedimentation takes place and the rivers turn into alluvial with poorly defined valleys with no apparent slopes. Sedimentation occurs due to the combination of valley unconfinement, sudden drop in the river gradient, and flow speed reduction. The unconfinement increases downstream with terrace slopes decreasing favoring overflow, crevassing, and channel splitting. Both channel bifurcation and sedimentation lead to changes in the position of channels, and, eventually, the main channel may fully change position and the river course shifts to another portion of the floodplain, a phenomenon termed avulsion.

The Pantanal is a large subsiding sedimentary basin that continuously creates accommodation space for deposition [15]. The rivers deposit sediments carried from the catchment-source area, filling portions of the basin, whereas other areas remain starved. Consequently, the river changes continually its position within the basin to distribute sediments all over the area, which means that the river behavior is avulsion dominated and the system is avulsive [16]. Fluvial avulsion is a step-bystep serial processing that abruptly shifts the river course.

Avulsive channel systems commonly lead to a fluvial distributary drainage pattern, characterized by networks of channels radiating from the apex of the system, with one or more perennial and many intermittent channels that are active only during floods. These systems are termed fluvial megafans and are distinguished from debris flow dominated alluvial fans not only because they are dominated by rivers, but also due to their large areas reaching $10^{3}-10^{5} \mathrm{~km}^{2}$ while alluvial fans are generally $<10^{2} \mathrm{~km}^{2}$ [17]. The Kosi River system in India is an example of large fans since Gole and Chitale [18] reported records of river shifts of $\sim 100 \mathrm{~km}$ from east to west across the fan surface, over a period of 230 years (17311963). The Kosi fan typifies braided river-dominated alluvial fans in the threefold classification of fluvial subaerial fans [19]. In this classification, the Okavango fan in Botswana is a suitable model for the second group of stream-dominated fans: the low sinuosity/meandering river-dominated fans.

The importance of fluvial megafans was recently emphasized by Weissmann et al. [20] and Hartley et al. [21], although they chose the term "distributive" (instead of distributary) and have referred them as distributive fluvial systems (DFS). The use of satellite images was crucial to recognize where large distributary systems occur today worldwide, and how they are strongly influenced by climate to establish fluvial drainage patterns [17, 20, 21].

The distributary drainage network and the dimensions of the alluvial systems of the Pantanal Basin [22-24] are typical of fluvial megafans [15]. The Taquari megafan is unquestionably the most studied of them and the largest distributary fluvial system in the basin with $\sim 50,000 \mathrm{~km}^{2}$ [25-28].

All Pantanal megafans are depositional systems driven by avulsive rivers. Fluvial avulsion is frequently an autogenic phenomenon since it emerges exclusively from intrinsic factors related to the construction and abandonment of depositional fan lobes. Fluvial avulsion is hence discernible from stream piracy, in which a river captures an adjacent river because of regressive erosion processes 
or crustal movements in active tectonic areas. Avulsion is very common because the rivers do not drift laterally and gradually in the plain, but shift suddenly to areas far from the active main channel. Shifts of the Taquari River course have been quite frequent in the modern distributary lobe. A remarkable avulsion took place during the 1990s in the lower course at the fringe of the Taquari megafan, in the locality named "Zé da Costa." The channel shifted $30 \mathrm{~km}$ northward its confluence in relation to its original mouth at Porto da Manga locality [25]. The avulsion was quick as time lapses only 10 years and the succession of events is very well documented in satellite images (Fig. 3).

An avulsion of greater magnitude has been evolving since the beginning of the 2000s near the apex of the modern fan lobe (Caronal farm), where the meander belt unconfines. Frequent overflow and many in the natural levees on the right margin of the Taquari River with drainage of sediment-laden waters have been diverting the flow to the floodbasin. The distributary channels distribute the sediments over a broad accumulating alluvial area where a new avulsion belt is under construction. The new channels divide into numerous channels with frequent rejoin characterizing an anabranching (multichannel) river system, but channels fade away downstream and the waters flow unconfined in an extensive floodbasin. Most of the river water is already flowing through those newly formed channels (Figs. 3 and 4), and the changing landscape has been documented by satellite images (e.g., [27]). The Taquari River can shift its course and abandon the main channel, changing its mouth a hundred kilometers toward north, as previously envisaged by Assine [25].

Avulsion commonly results from the association of many factors, and the triggering occurs during a discharge event of magnitude at or near the avulsion threshold [29]. Although there is no consensus on the causes that initiate the avulsions in the Taquari megafan, one of the most important causes for avulsion is the channel aggradation [25, 27, 30]. Zani et al. [28] pointed out that avulsions are occurring progressively closer to the apex (intersection point of the megafan) and suggested that the system is being filled in a toe-to-apex direction. Based in these observations, they concluded that the base level is above the longitudinal profile downstream of the intersection point, where accommodation space is available for in-channel sedimentation, which causes avulsion triggering.

Flow deceleration downstream of the intersection point results in the channel aggradation and riverbed shoal formation (Figs. 3 and 4). Progressively the channel belt becomes a few meters higher than the adjacent floodbasins because of the aggradation inside the channel and increasing height of marginal levees, causing the channel to lose capacity to convey flood discharge. Channel overflow and crevassing (arrombados) create favorable condition for avulsion, beginning with channel splitting. The process can be very rapid because the slope down to the adjacent floodbasin is higher, diverting the flow and causing the abandonment of the main channel (Fig. 5).

Avulsive river shifting in the modern distributary lobe of the Taquari River is a natural response of the system to accommodate sediment supply coming from the catchment area. In this context, channel aggradation has been likely intensified by land use (livestock and farming) in the basin highlands [31, 32]. Besides, river 


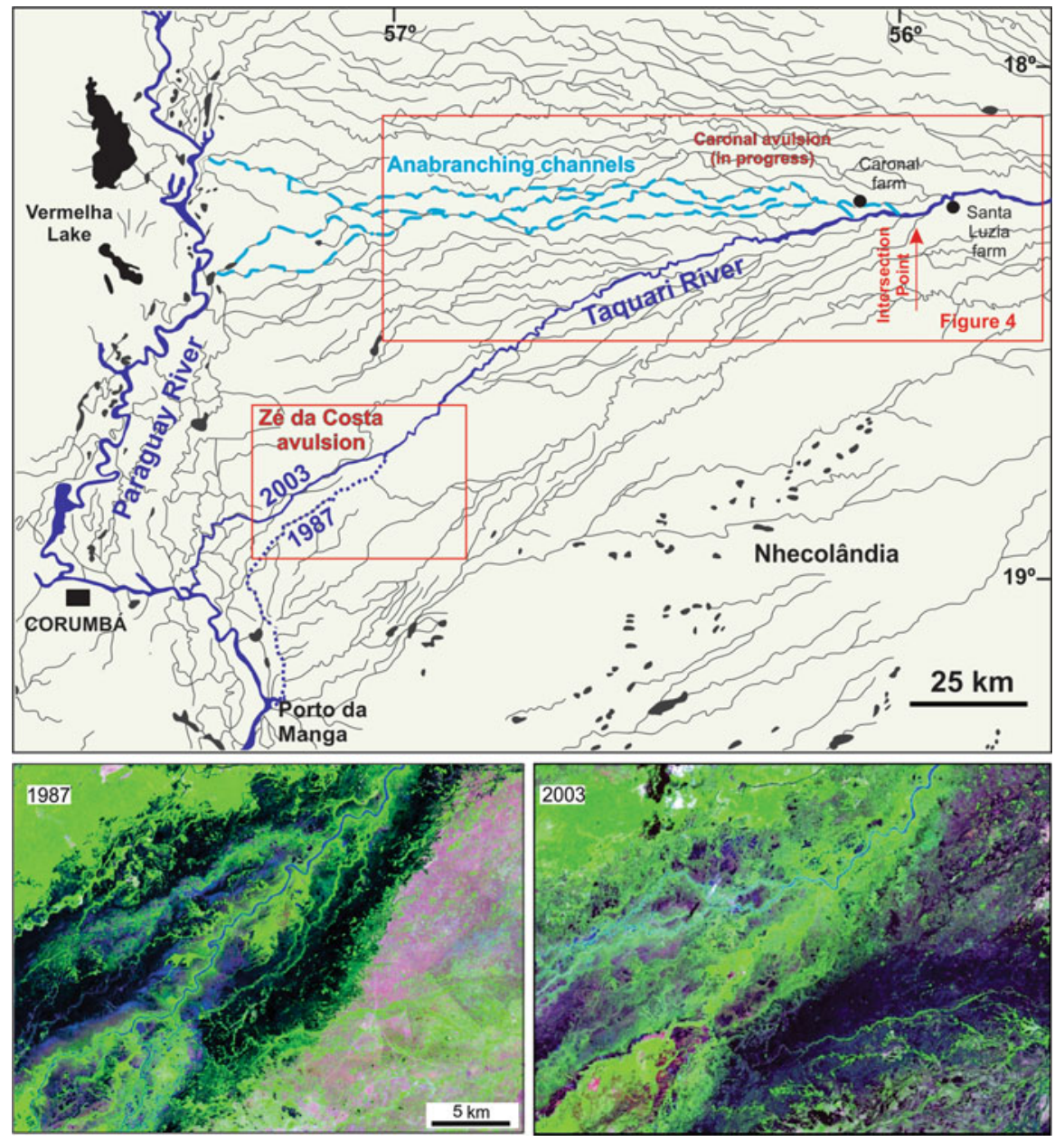

Fig. 3 Avulsions on the modern depositional lobe of the Taquari megafan (IP = intersection point). A large-scale avulsion is in progress at the apex near the intersection point of the megafan at the Caronal farm. The new distributary channels on the right margin of the river envisaged by Assine $[23,25]$ are now very active draining more the $70 \%$ of the river discharge and shifting approximately a hundred kilometers north from its confluence with the Paraguay River. The wellknown "Zé da Costa" avulsion has occurred in a time lapse of two decades, as documented by multitemporal Landsat images taken in 1987 and 2003 (false-color composition R7G4B3)

avulsions in lowlands may also result from increased rainfall since 1973, following a very dry decade.

Despite the recently anthropogenic interference, avulsion is a geomorphologic result of a natural depositional mechanism in fluvial megafans. The São Lourenço megafan gives us an important evidence of this natural behavior. The "Boca Brava" avulsion (Fig. 6) caused the abandonment of its former main channel, the "Braço do São Lourenço," and the confluence with Piquiri River and shifted the river to its 

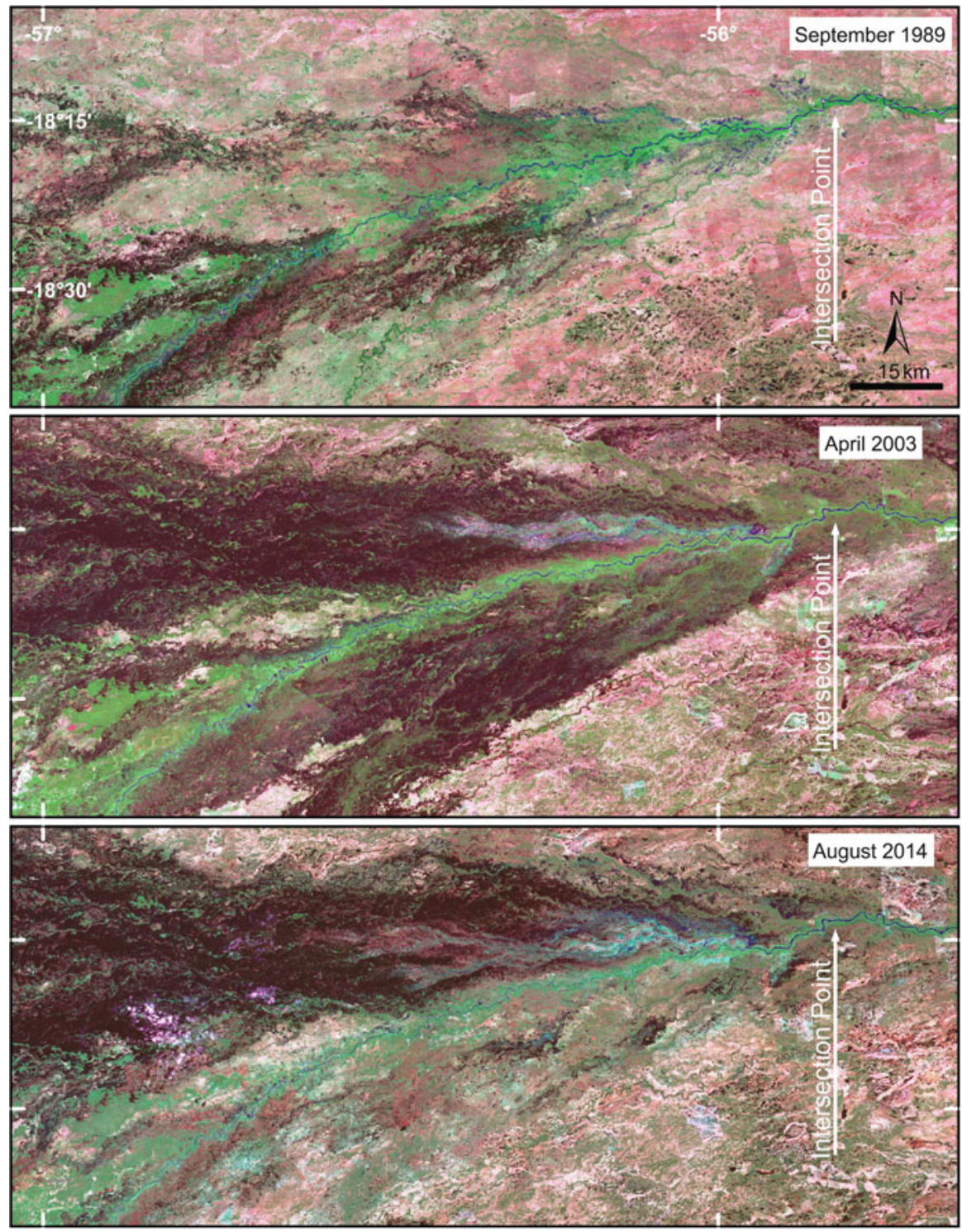

Fig. 4 Channel changes and the deposition of an avulsion belt associated with the Caronal avulsion as seen in multitemporal satellite images taken in 1989, 2003, and 2014. (Satellite images: 1989 TM5 R7G4B3; 2003 ETM+ R7G4B3; 2014 OLI R7G5B3)

present course and actual confluence with the Cuiabá River [33]. The shift took place between 1890 and 1915 [33] and indicates that avulsions in the Pantanal are commonplace, independently of accelerated sedimentation due to anthropogenic activity, which became much more intense with agricultural and ranching practices 

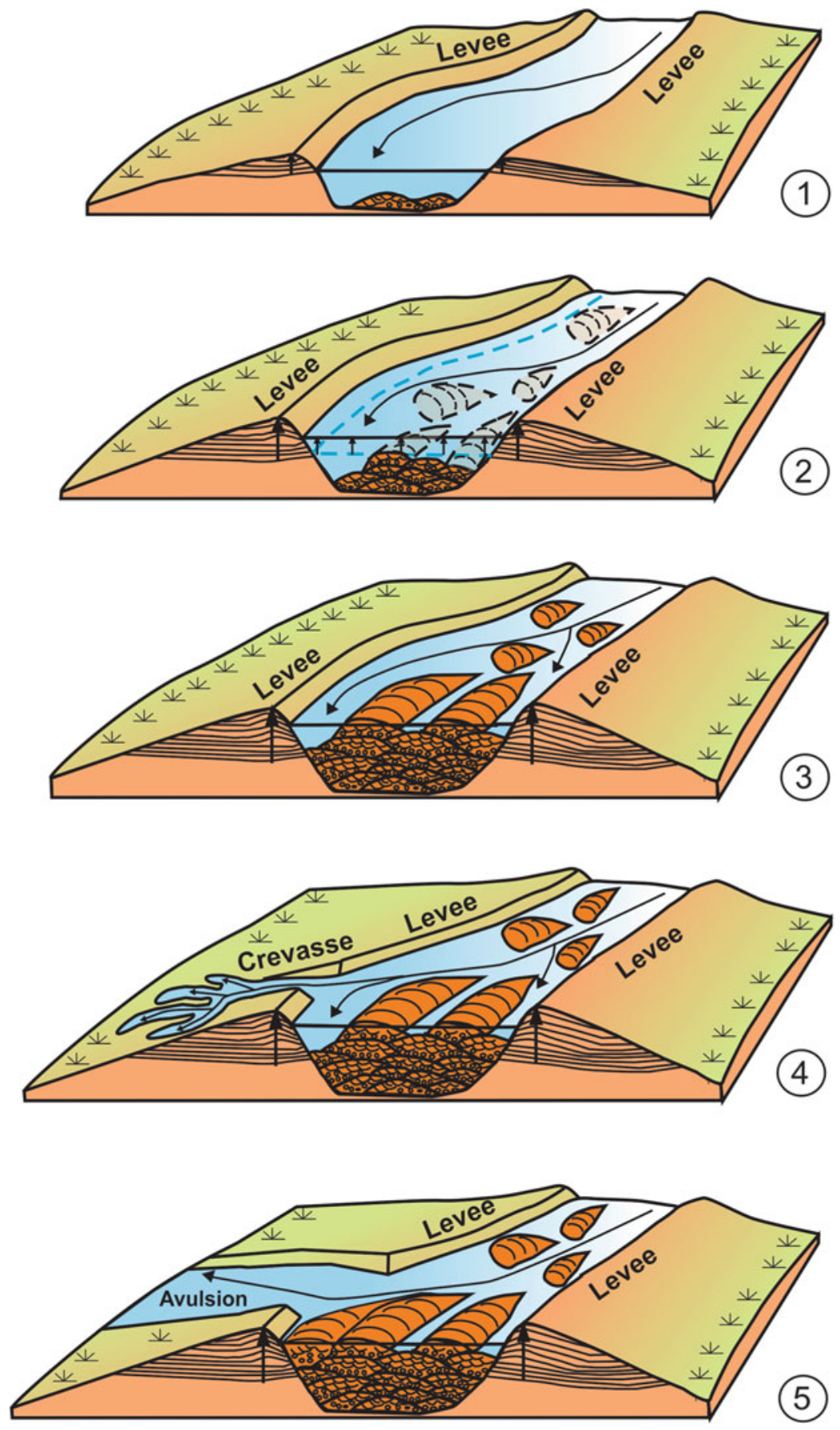

Fig. 5 Schematic evolution of the phenomenon of channel splitting and avulsion of the Taquari River [26]: (1) the channel steadily rises in relation to its adjacent areas due to the levees built through subsequent seasonal flood overflows. (2) The riverbed rises through sediment aggradation 


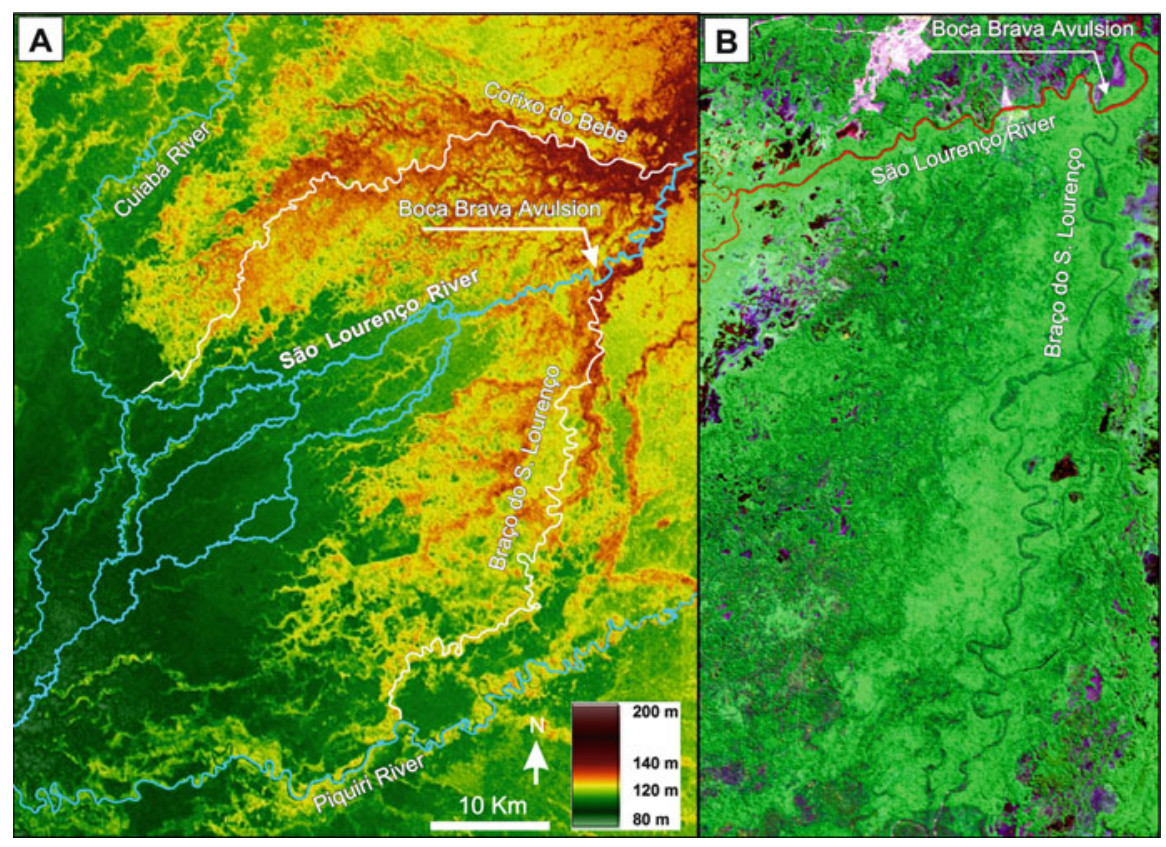

Fig. 6 Avulsion and establishment of distributary channels in the modern depositional lobe of the São Lourenço megafan. Left-sided image is SRTM data, and the right-sided image is a box section obtained by false-color band composition of Landsat TM data, GeoCover, RGB742, 1990

after the 1970s. The time span ( $<25$ years) is similar to the rate of recent avulsions observed in the Taquari megafan [25]. The abandoned "Braço do São Lourenço" channel now behaves solely as an intermittent stream flowing during wet seasons, but remains a prominent morphologic feature on the landscape. Nowadays, sedimentation on the active depositional lobe of the "São Lourenço" megafan occurs in its most distal position, between the "Corixo do Bebe" and the "Braço do São Lourenço" abandoned lobes, an area with available accommodation space where river splits into two or more distributary channels, each one presenting many divides and rejoin (Fig. 6).

The Paraguay River itself has been building a large megafan at the river entrance into the northwestern border of the Pantanal. The drainage pattern is distributary on the modern depositional lobe, and the Taiamã Island resulted from the split off and rejoin of the main channel [35]. Minor avulsions have commonly occurred in this

Fig. 5 (continued) in the channel and in the marginal levees. (3) Following the silting process of the channel, the sand bars emerge even in flood times, causing reduction in channel capacity of water retaining. (4) Sooner or later, a seasonal flood induces the crevassing of the marginal levee and the splitting of the channel. (5) The water flow is steadily diverted to the new channel and, finally, the river changes its course with the abandonment of the main channel 

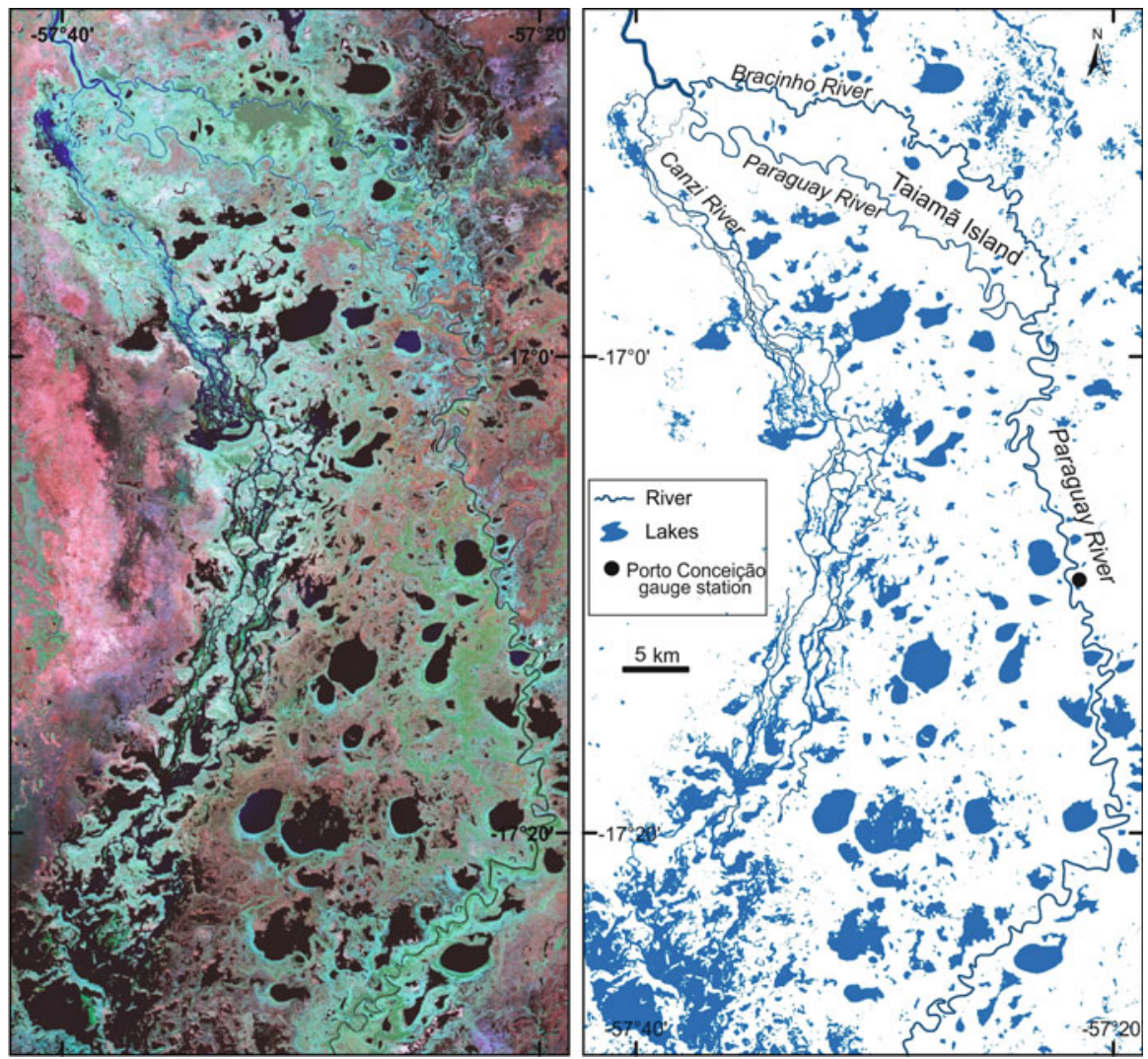

Fig. 7 Avulsion in progress on the right margin of the Paraguay River upstream of the Taiamã Island. Waters from the diverting channels are contributing to form the anabranching channels of the Canzi River

modern distributary lobe, as indicated by many abandoned channels within the floodplain. Emphasis must be addressed to an important avulsion in progress upstream of the Taiamã Island, where water is flowing out from the channel through some crevasses on the right margin of the Paraguay River. This pattern suggests a probable abandonment of the present channels of the Paraguay River and a future attachment of the Taiamã Island to the floodplain (Figs. 7 and 8).

Successive dividing and rejoining results in an anabranching fluvial pattern, which characterizes many reaches of modern depositional lobes of Taquari and São Lourenço River megafans. The Cuiabá River also exhibits anabranching channels in the modern depositional lobe, but differently from the former, it presents important reaches characterized by the existence of multiple small channels in the upper megafan setting [36].

Multiple dividing and rejoining river channels encompass a wide variety of river patterns, referred elsewhere as braiding, anastomosing, or anabranching which can 

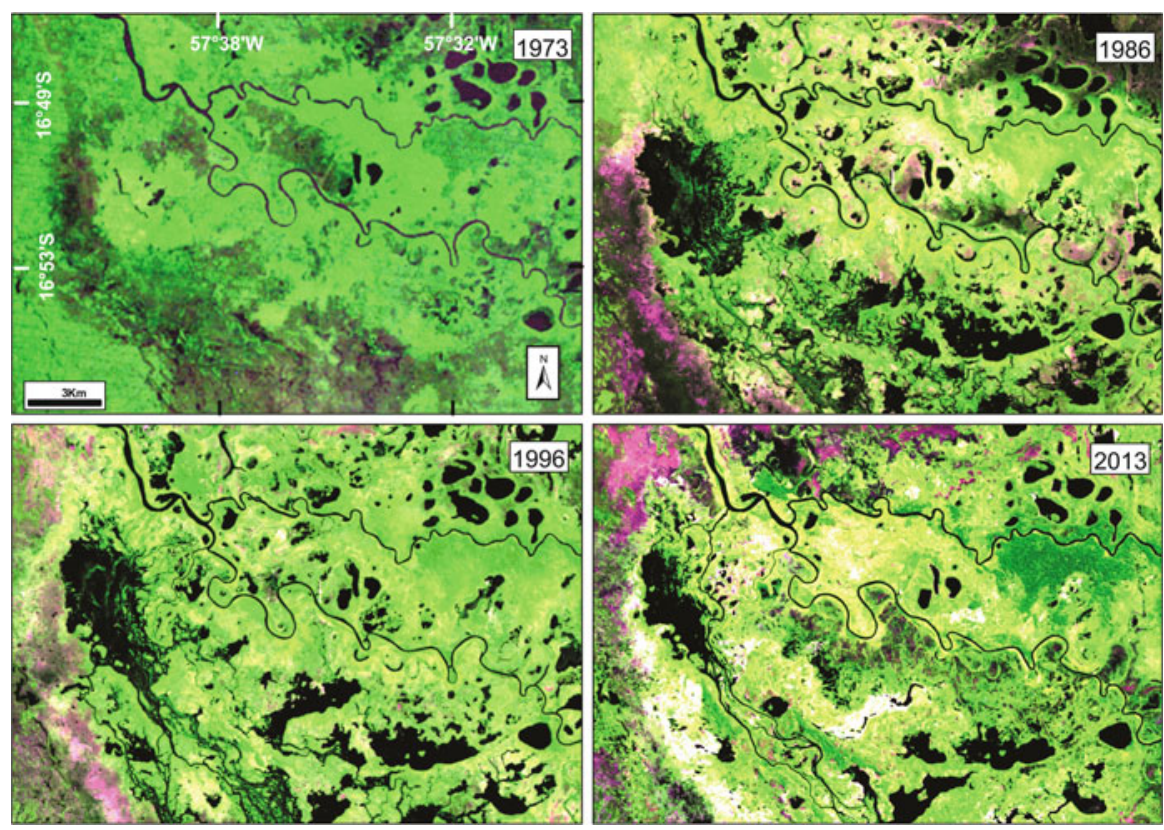

Fig. 8 Crevassing and diverting channels on the right margin of the Paraguay River as seen in multitemporal satellite images (Landsat 1 MSS, RGB475, August 1973; Landsat TM5, RGB547, October 1986; Landsat TM5, RGB547, July 1996; and Landsat 8 OLI, RGB657, June 2013

be referred altogether as multichannel rivers [37]. Despite the differences in channel style, multichannel rivers are present in the Pantanal wetland, not only in the fluvial megafans, but also along the Paraguay River main stem. The Paraguay flows from its catchment at north to the exit of the Pantanal wetland, crossing a heterogeneous floodplain and collecting the waters from the whole basin. Multichannels are present in many geomorphic zones of the floodplain, and their importance to the Pantanal hydrology is presented in the following section.

\section{Depositional Tract and Surface Hydrology Dynamics}

Flowing from southward along the western margin of Pantanal wetland, the Paraguay River is the mainstem river of a depositional tract composed of many fluvial megafans and interfan systems, lakes, and swamp areas (Fig. 9; see [15]). Accordingly, the drainage system is very complex due to the coexistence and interaction of these different systems. Within the Pantanal, the drainage networks display channel bifurcations and avulsions in the megafan distributary systems, and multichannel reaches are frequent in the modern megafan depositional lobes, as well as in the Paraguay River mainstem plains. These peculiarities cause a very complex flood 


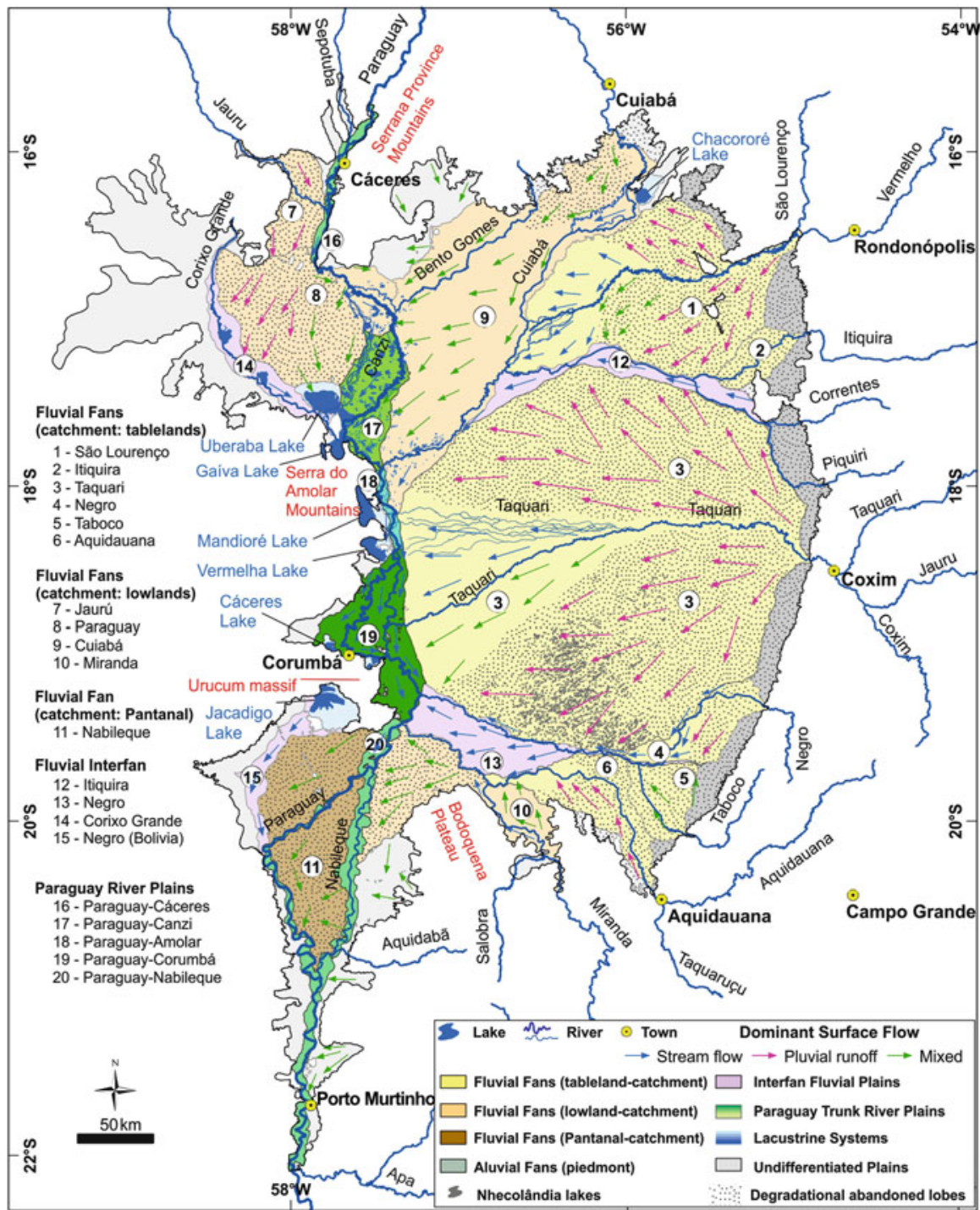

Fig. 9 The Pantanal alluvial depositional system tract with drainage pathways (streamflow, pluvial runnof, and mixed flow) [33]

regime within the Pantanal wetland with ecological and socioeconomic implications.

The hydrology of the Upper Paraguay Basin is very complex [38]. Rivers in the catchment area have comparable regimes with strong direct in-phase correlation between rainfall and discharge (Fig. 2), but in the fluvial megafans, the peak of fluvial discharge occurs one to two months after maximum rainfall. In the fluvial 
megafans, meander belts are confined in the upper fan and the river works as a bypass transporting water from the catchment area directly to the modern lobes, and the abandoned lobes do not receive water from the river. In the abandoned lobes, the surface runoff is essentially pluvial during floods and sustained by subsurface return flow (throughflow) after flood peaks. Outflow of the ground in springs is the source of water to many small streams (named "corixos") that drain the surface of abandoned lobes following the wet season. Some of these abandoned lobes, especially those of the megafans situated on the south portion of the Pantanal (Aquidauana, Miranda, and Nabileque), are characterized by mixed surface runoff because there are contributions of pluvial water as well as sheet flow from unconfined fluvial waters (Fig. 9).

In general, the fluvial fans of the Pantanal have a concave-down morphology that favors the water dispersion, preventing water retention. The Taquari and São Lourenço megafans exemplify the morphological control on water transfer (Fig. 10). In the upper portion of the fan, the river is normally incised and runs in a narrow meander belt entrenched on their ancient lobes. The active lobes have a grossly triangular shape with the vertex toward the fan apex. Sedimentation processes are very active in these sites, avulsion being the main fluvial phenomenon of sediment dispersal. Following avulsion, the river becomes unconfined and the waters flow radially by a system of distributary and anabranching channels.

The hydrographs of the Taquari and São Lourenço rivers show that during mid-lower water level, the flow occurs only in the channel, both for the incised and anabranching reaches (Fig. 10). As these rivers do not receive any tributary along the fan, the discharge measured in the upper, mid, and lower gauge stations are practically the same. However, during the flood pulse, the gauge stations in the anabranching reach of both rivers show an impressive loss of water for secondary anabranching channels. Differently from common fluvial basins, the channel belt in the uppermost portions of the fluvial plain is a bypass and works as a "drainage divide" for surface runoff. The Hortonian flow lines drawn over the topographic maps of the Taquari and São Lourenço fluvial fans indicate a dispersive trend of water from the channel belt toward the fan fringes (Fig. 10).

The Paraguay River collects water from multichannel streams present in the modern distributary lobes of fluvial megafans and from streams of interfan fluvial plains, each one with very different hydrological functioning. Hydrographs along the Pantanal mainstem river display an opposite behavior relatively to the rivers in the catchment area (Fig. 2). Whereas the fluvial discharge in the catchment area (Cáceres, Barão de Melgaço, and Coxim stations) varies in phase, in São Francisco and Porto Murtinho stations, respectively, at the center and at the end of the Paraguay River plain, the discharge varies out of phase with local rainfall.

The historical gauge station series of the Pantanal rivers vary in data extension, continuity, and quality. Collischonn et al. [39] identified for the Ladário gauge station - the longest historical series constructed since 1900 - a period of low hydrometrical level from 1962 to 1973 followed by the present period of high hydrometrical level. An expedite hydrological comparison between dry and humid periods measured for eleven gauge stations along the Paraguay River shows a 

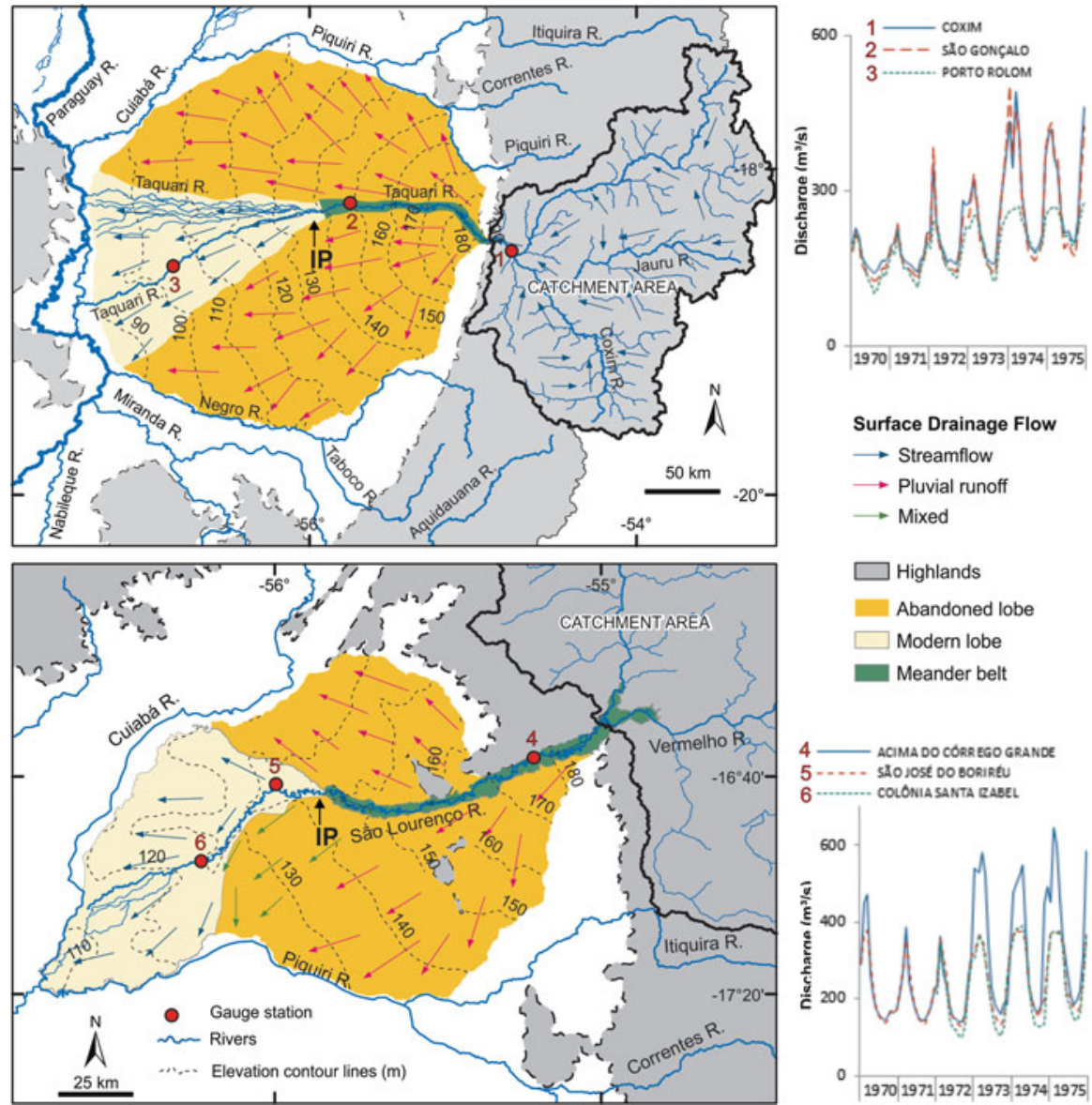

Fig. 10 Surface hydrology of the two large Pantanal megafans: Taquari (upper) and São Lourenço (lower). Both megafans are characterized by similar morphology and surface hydrology. Water from catchment areas reach the modern depositional lobes through feeder channels confined in meander belts entrenched in the upper fan (IP = intersection point). Abandoned lobes in both systems do not receive water from the catchment nor directly from the feeder channel, and most of the flooding comes from pluvial runoff. The rivers lose water to the floodplain in the modern depositional lobes, especially during rainy years, as occurred in 1974-1978 when the monthly mean discharge was higher than previous years. Hydrographs presented on the right refer to gauge stations: Coxim (1), São Gonçalo (2), Porto Rolom (3), Acima do Córrego Grande (4), Colônia Santa Izabel (5), and São José do Borireu (6)

difference from $81 \%$ in the annual average discharge at Porto Murtinho gauge station (Fig. 11). The intense land-use change in the Pantanal highlands during the last four decades also contributes to significant changes in the ecohydrology [40] of the Pantanal. Forest suppression in highlands for crop and livestock [41-45] is responsible for increasing river discharge while reducing evapotranspiration and 

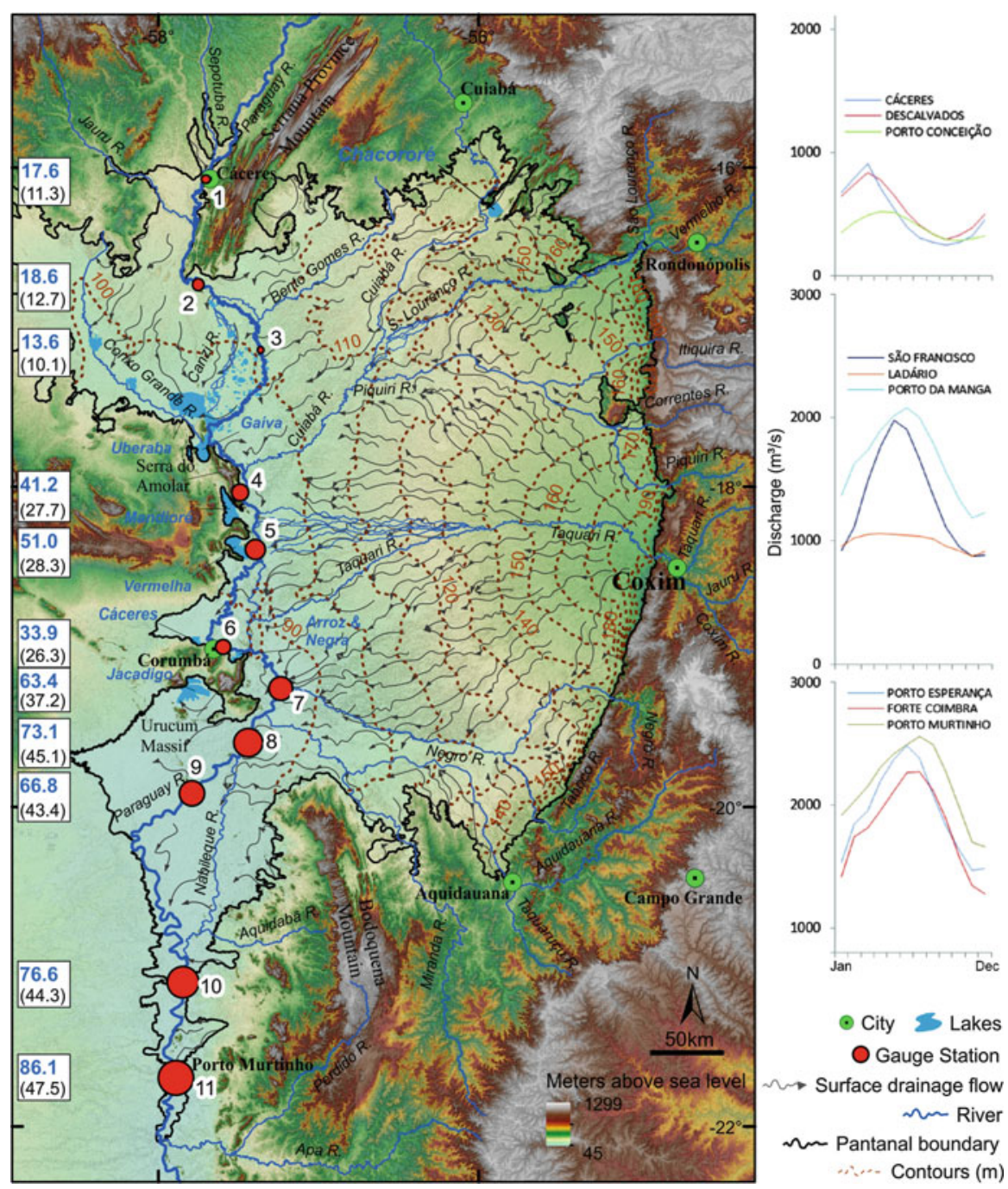

Fig. 11 The Pantanal hydrology of the land surface system. The main rivers are represented as well as runoff pathways (sinuous arrows) of surface waters extracted from the SRTM data. Numbers in white boxes are the mean total annual discharge $\left(\mathrm{km}^{3}\right.$ year $\left.{ }^{-1}\right)$ at each gauge station during the dry 1970-1974 period (black) and during the 1974-1978 humid period (blue). Gauge stations in the Paraguay River: (1) Cáceres, (2) Descalvados, (3) Porto Conceição, (4) Amolar, (5) São Francisco, (6) Ladário, (7) Porto da Manga, (8) Porto Esperança, (9) Forte Coimbra, (10) Barranco Branco, and (11) Porto Murtinho. The flood wave from north to south is evident in hydrographs of nine of these gauge stations, grouped in sets of three according to its geographical position: upstream (Cáceres, Descalvados, and Porto Conceição), middle (São Francisco, Ladário, and Porto da Manga), and downstream (Porto Esperança, Forte Coimbra, and Porto Murtinho) 


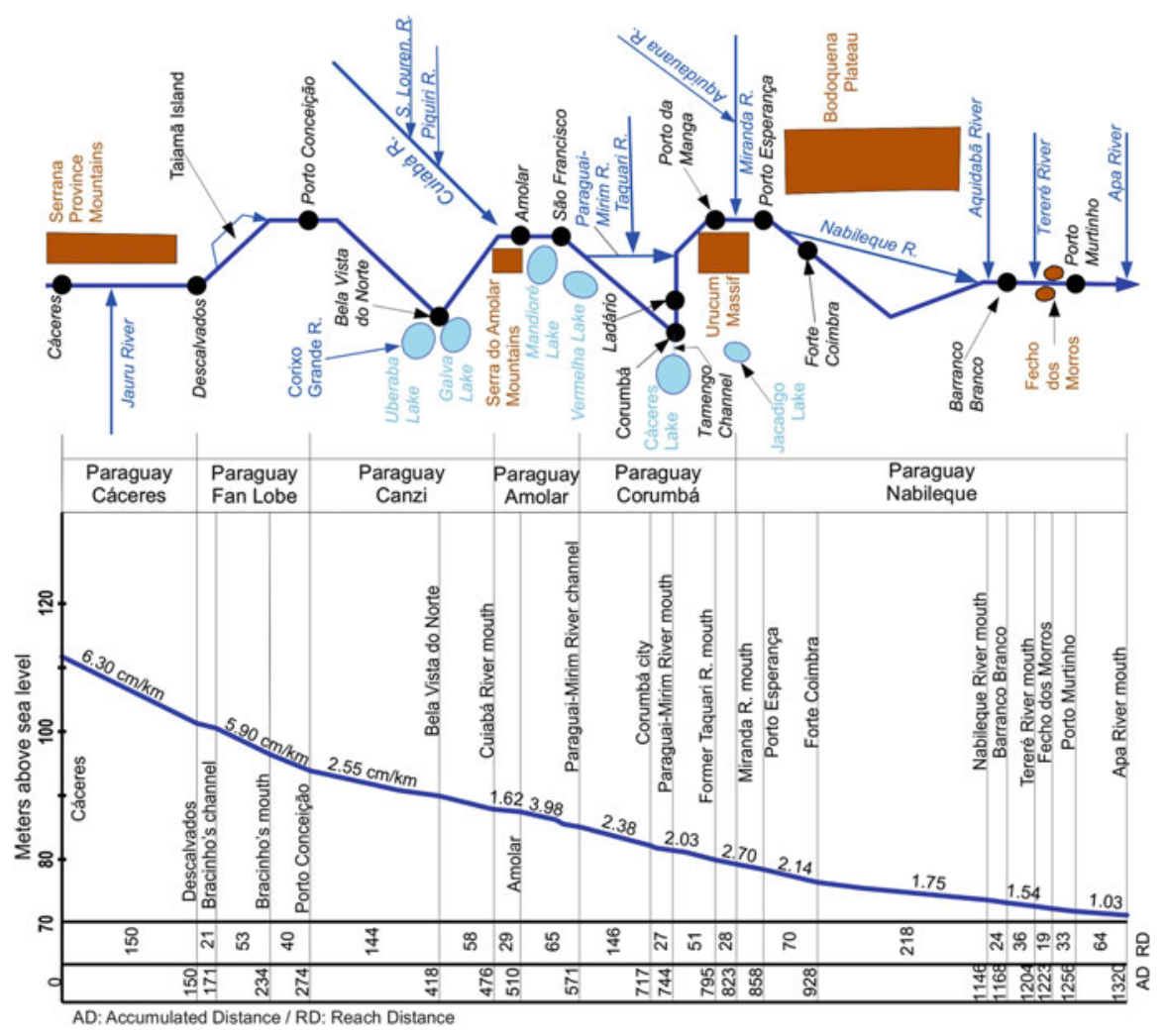

Fig. 12 Hydrographic scheme of the Upper Paraguay River in relation to its gradient profile (not to scale). Longitudinal profile was based on data of Franco and Pinheiro [47]

cloud formation in highlands [32] that could distribute rainfall in lowlands areas without floodplains as the Nhecolândia [46].

The Paraguay River plain has geomorphologic heterogeneity in consequence of its geologic position on the western faulted border of the sedimentary basin [15]. The river-mainstem plain comprises five distinct fluvial floodplain compartments, each one presenting different morphologic characteristics, channel pattern, and hydrologic functioning (Fig. 9). The Paraguay River floodplain is variable in style and width, reflecting tectonic control on the western margin of the Pantanal basin and interaction with the distal portion of fluvial megafans. The longitudinal profile of the Paraguay River shows subtle knickpoints in the limit of these compartments (Fig. 12).

The northmost Paraguay-Cáceres river plain compartment, located at the entrance of the Pantanal (Fig. 9) and ending in the farm of Descalvados (gauge station number 2 on Fig. 11), is a 4-5-km-wide confined floodplain, limited by the Jaurú fluvial fan at the right side and the NE lineaments of Serrana Province Mountains at the left margin. The river channel has irregular meanders with some 
small anabranching channels, oxbow lakes, and island along this reach. The flood pulse is coincident with austral summer precipitation, and both Cáceres and Descalvados hydrographs show approximately the same behavior with a small increase in the annual discharge in Descalvados station, which results from the confluence of the Jaurú River in the middle of reach (Fig. 11).

Leaving the confined Paraguay-Cáceres river plain, the river forms the modern lobe of the Paraguay megafan ([35]; Fig. 9), an active depositional lobe characterized by two main anabranching systems. An important bifurcation of the Paraguay River channel (Bracinho River) and the downstream channel rejoining form the 30-km-long Taiamã Island. Recently, crevasses upstream of the Taiamã Island are diverting important water flow into the floodplain on the right margin of the river, turning the Canzi River a multichannel system with many anabranching channels (Fig. 7). A comparison among hydrographs of gauge stations situated upstream (Cáceres and Descalvados) and downstream (Porto Conceição) of these crevasses confirms important loss of water to the Canzi River during the river peak discharge (Fig. 11). When water level is sufficiently high, the Paraguay also loses water southward as sheet flow over the surface of the abandoned lobes. Myriad small lakes in the floodplain accumulates large amount of water diverted from the main channel and contributes to retarding the flood wave.

The Paraguay-Canzi plain is a compartment with reduced river gradient in relation to the upstream reaches (Figs. 9 and 12). The floodplain is a large area of active sedimentation, receiving water and sediment from the Paraguay and Canzi rivers. The plain also receives water and sediments from the Cuiabá River. A large number of lakes form in the floodplain, including the largest Uberaba and the Gaíva lakes. The water accumulation in this lake-floodplain is so forceful that the peak in the Amolar gauge station, at the end of this floodplain, occurs in May-June, about 60 days after it passes by Descalvado gauge on March. The Paraguay-Amolar floodplain produces a bottleneck effect on the water coming from the Paraguay and Cuiabá, incurring the delay of the flood-pulse wave. Such a huge mass of dammed water accumulates in the Paraguay-Canzi floodplain, feeding lakes and swamps and producing a huge continuous water body of more than $10,000 \mathrm{~km}^{2}$ during June and July (Fig. 13). The importance of this area in the hydraulic regulation of the Upper Paraguay River was highlighted in the report [48].

The Paraguay-Amolar is a narrow floodplain limited by the Serra do Amolar mountains and the Cuiabá and Taquari megafans that conjointly acts as a bottleneck for the flow of the Paraguay River (Figs. 9 and 13). It has about $53 \mathrm{~km}$ long, ending with the floodplain extension near the Vermelha Lake. Despite only $6 \mathrm{~km}$ wide, the Paraguay-Amolar floodplain has empty spaces constituted by the large Vermelha and Mandioré lakes and a series of irregular water bodies covered by floating macrophytes and cut by channel-levees. The Cuiaba River that flanks the eastern side of the floodplain also supplies the area with large amount of sediment through crevasse splays (Fig. 13). The reach is also influenced by the Cuiabá and the north portion of the Taquari active fans (Fig. 9), which supplies with water the Paraguay through many anabranching distributive channels. Thereby, the hydrograph of the São Francisco gauge station in the middle portion of the reach also shows it flood- 

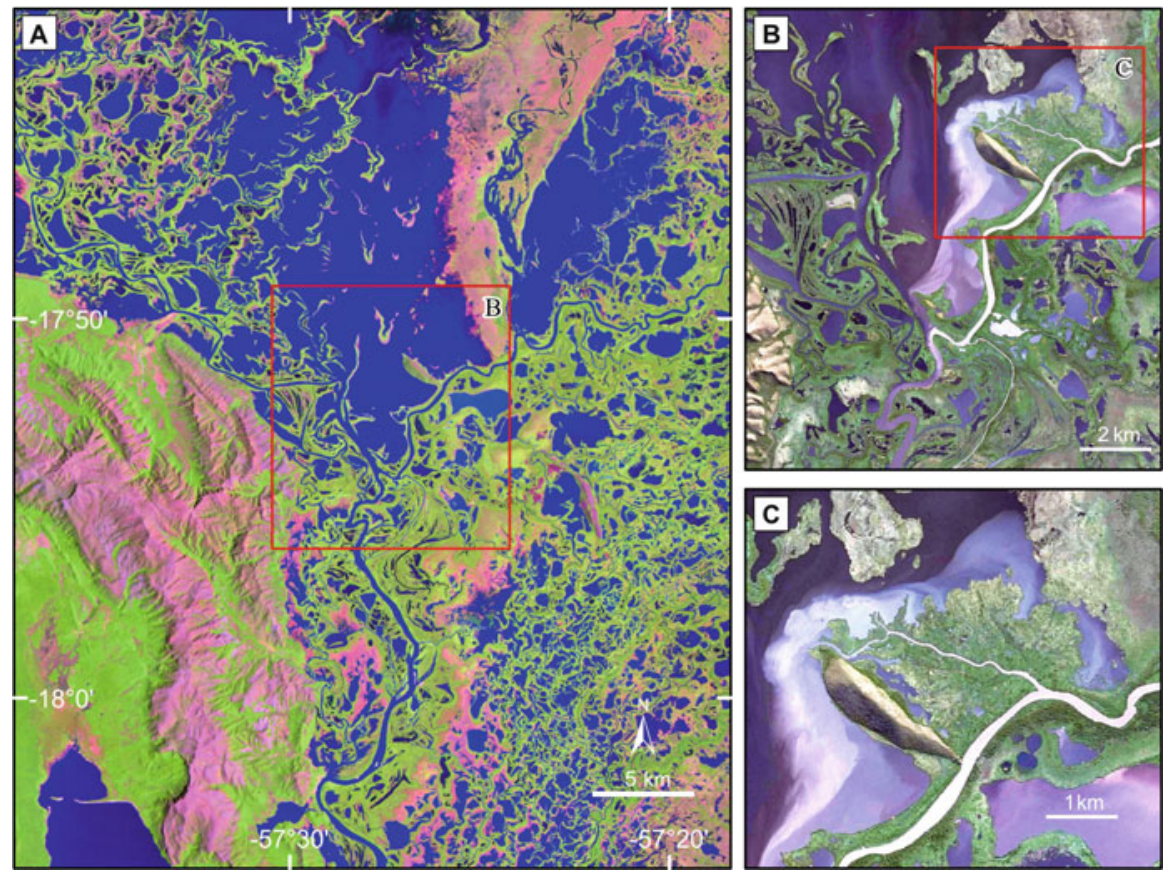

Fig. 13 Narrow river plain in the Serra do Amolar bottleneck causes flow constriction and backwater flooding upstream. (a) In consequence, the water level rises in the floodplain of the Paraguay and Cuiabá rivers, as well as in the Uberaba and Gaíva lakes, creating a large area often inundated (Satellite image Landsat 5 TM, R5G4B3, from December 1985). (b, c) The reduction in sediment load transport makes this area a site of active sedimentation, exemplified by crevasse splays in the lower course of the Cuiabá River

pulse peak on May, about three months later than in those verified for Cáceres and Descalvados stations.

Placed downstream of the Vermelha Lake, the Paraguay-Corumbá compartment is a $27-\mathrm{km}$-wide plain drained by an anabranching reach formed by the Paraguay and the Paraguai-Mirim rivers. This flat floodplain (slope around $2.3 \mathrm{~cm} / \mathrm{km}$ ) is not homogeneous but covered by paleochannels of anabranching channels of the ancient Paraguay River ([49]; Fig. 14). Inactive during the low-medium water level, these paleochannels receive water during the flood, so that flood-pulse peak takes a month to run from São Francisco to Porto da Manga gauge stations, the last one located near the mouth of the Miranda River at the end of the ParaguayCorumbá river plain. The hydrographs of São Francisco and Ladário gauge stations show that $10 \%$ of the Paraguay discharge is diverted to the Paraguai-Mirim. However, this difference increases twofold during the flood (Fig. 14). The narrowing of the Paraguay floodplain near the mouth of the Miranda River, constrained by the highlands of the Urucum Massif and the fringe of the Miranda fluvial fan, constricts the river flow and functions as a second bottleneck along the Paraguay River course (Urucum Bottleneck). 


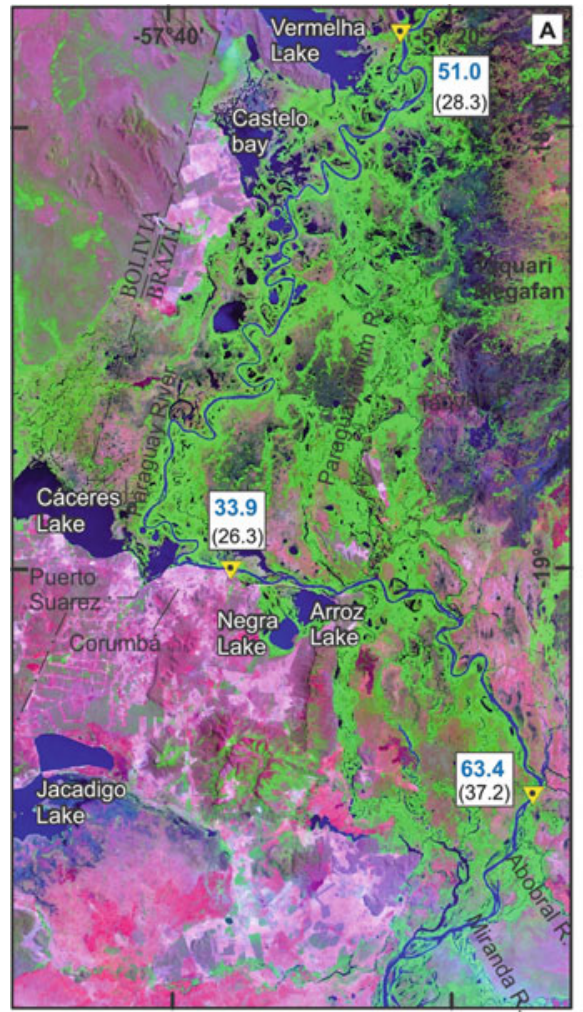

Abandoned meander belt $\quad$ Active meander belt Undifferenciated plains $\sim$ River $\$$ Lake

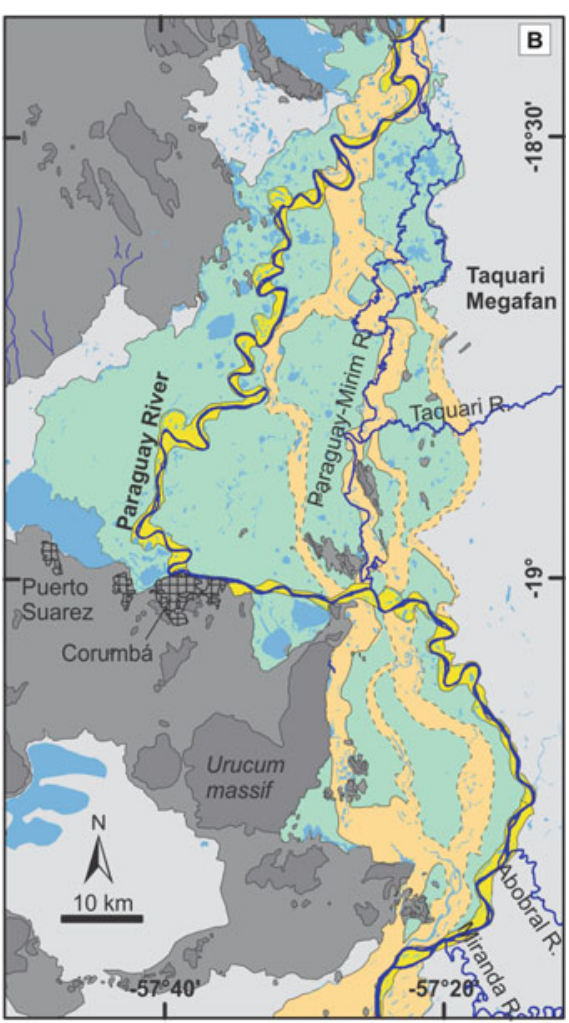

Paraguay floodplain Lowlands Highlands - International border $\bullet$ Gauge station

Fig. 14 Hydrology in the large Paraguay-Corumbá plain is strongly controlled by active landforms. This reach of the Paraguay River is marked by abandoned meander belts, where the Paraguay River channels were formerly placed before its avulsion to its actual meander belt. Many lakes are closely influenced by the Paraguay flooding dynamics. (a) Landsat 7 ETM+ (R7G4B3) image from September 1999; (b) geomorphological map showing distinct zones and paleo landforms (after [49]). Numbers in white boxes are the mean total annual discharge $\left(\mathrm{km}^{3}\right.$ year ${ }^{-1}$ ) at São Francisco (5), Ladário (6) and Porto da Manga (7) gauge stations during the dry 1970-1974 period (black) and during the 1974-1978 humid period (blue)

Downstream the confluence of the Miranda River, the Paraguay River enters in a less subsiding area at the south portion of the wetland. In this area, the actual meander river belt cut the Pleistocene deposits of the Nabileque megafan [50]. Remarkable is the presence of a large paleomeander belt of the Paraguay River in which today the Nabileque River flows as an underfit stream resulted from an important avulsion occurred around 4,000 years ago ([51]; Fig. 9). Comparing the hydrographs of Porto Esperança, upstream of the avulsion point, with Forte Coimbra, located downstream of the avulsion point, it is possible to verify that the Paraguay River loses about $10 \%$ of its water to the Nabileque River during the flood seasons (Fig. 11). 


\section{Hydraulic Bottlenecks and the Flooding Wave}

Inundation dynamics in the Pantanal wetland are greatly dependent of its geomorphology and many attempts to define patterns and forecast river water levels were made [52-56]. The inundation paths result from the intricate pattern of interconnected fluvial fan and interfan systems that link many catchment areas. The complex flooding wave is also constrained by the heterogeneous Paraguay River plains, formed by alternation of extensive floodplains separated by natural bottlenecks.

The structure and function of the flow dynamics of these floodplains are very important for navigation as well as for the sustainable exploitation of the ecosystem services provided by the Pantanal wetland (including tourism; see [57]). The more impressive and important hydrological phenomenon in the Pantanal is the backwater effect produced by the narrow reaches of Paraguay-Amolar and ParaguayNabileque over their respective upstream reaches. The flood permanence is always larger than 50\% with extremes of 85\% (ANA/GEF/PNUMA/OEA 2005).

Backwater is controlled by geological features reflected by knickpoints in the river longitudinal profile (Fig. 12). Furthermore, gauging backwater reaches is very difficult because the relation between water level and discharge during the flood is unclear (Ponce, op. cit.). Through satellite image, however, it is possible to identify the influence of the bottlenecks of Serra do Amolar and Urucum that favors water accumulation in the upstream reaches of Paraguay-Canzi and Paraguay-Corumbá, respectively (Fig. 15).

ANA/GEF/PNUMA/OEA (2005) report presents a simulation for the ParaguayCanzi river compartment considering a water level elevation of $1.0 \mathrm{~m}$ in the Amolar gauge station. The backwater extends by $270 \mathrm{~km}$ from Amolar up to the Descalvados gauge station. Under this condition, the average hydraulic slope is reduced from 3.5 to $1.8 \mathrm{~cm} / \mathrm{km}$, whereas the discharge remains constant $\left(943 \mathrm{~m}^{3} / \mathrm{s}\right)$. A continuum backwater includes waters from both the Paraguay River and the lower Cuiabá River (Figs. 13 and 15).

A comprehensive view of Pantanal flood dynamics is depicted in Fig. 16. Nine satellite images (MODIS data) in the hydrological year of 2006 compose a temporal window of the wave, flood-pulse advancement, the bottleneck damming effects, water transference, and the strong control of tributary fans over the hydrology in the mainstem river. The Pantanal is fully dry in the beginning of January. The areas of permanent water accumulation are restricted to floodplain lakes and to some portions of the active lobe in the Taquari River megafan. During the dry period, water flows only through river channels. The flood initiates on January, and the Paraguay-Canzi river plain starts to flood due to the bottleneck effect imposed by the Sera do Amolar and the Cuiabá River plains. Up to April, all floodplains upstream of the Paraguay-Amolar bottleneck are completely flooded. Some areas of the active and ancient lobes of the Taquari River megafan are also flooded. On May, the Paraguay-Corumbá river plain is also flooded, and the huge water body includes the active portions of Taquari megafan. On June, the flood spreads over all 

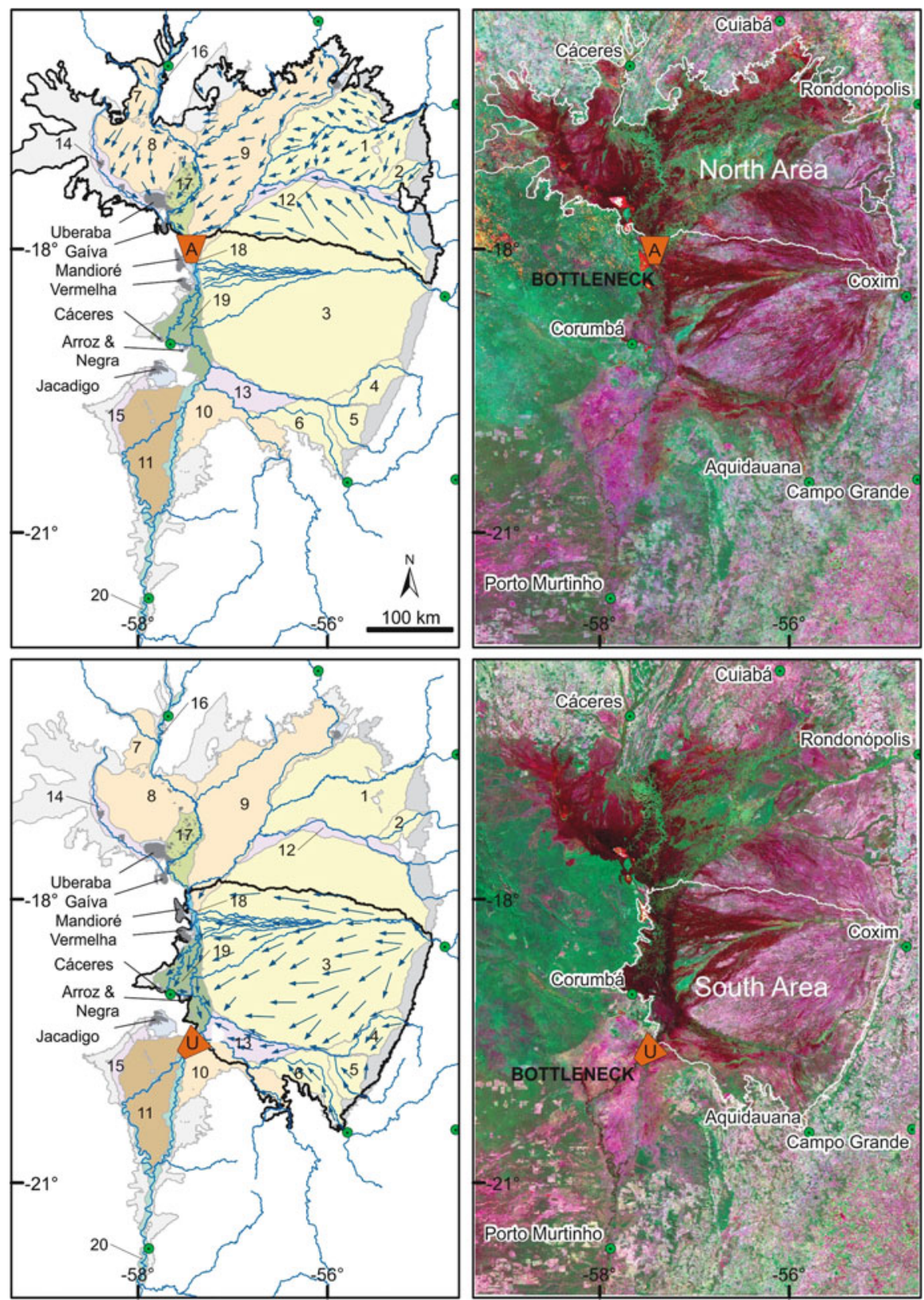

Fig. 15 The two bottlenecks that exert strong control (damming effect) on the flooding extent, magnitude, and duration in the Pantanal wetland. The Serra do Amolar bottleneck (A) delays the northerly flood-pulse wave. The Urucum bottleneck (U) slows down the flood-pulse wave southward and enhances the inundation in the Paraguay-Corumbá plain, in the fringe of the Taquari megafan and in areas draining to the Negro River interfan floodplain (numbers refer to depositional systems as identified in the Fig. 9) 

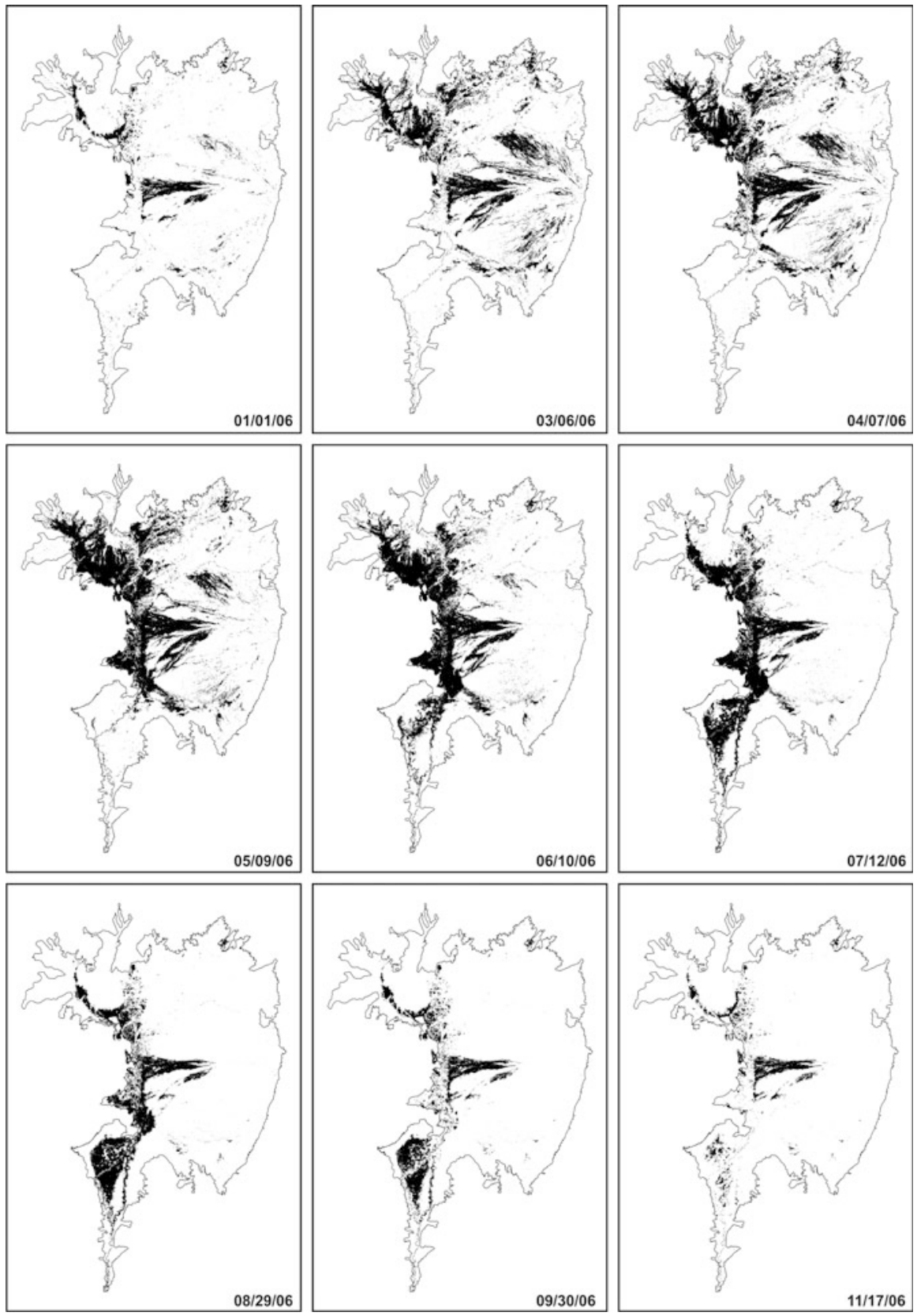

Fig. 16 Synoptic view of the annual spatial and temporal flood-pulse dynamics in 2006 (January to November) based on multitemporal MODIS images [54]. The successive images record the water transfer from borders to center and from north to south and how bottlenecks are effective in damming the water flow and enhancing the upstream floods. The effect of the Urucum bottleneck is clear after comparing images from May 9 to August 29 
the Pantanal including the Paraguay-Nabileque river plain that begins to be flooded. On July, the upper plains start draining, and the flood in the Paraguay-Nabileque reaches its maximum. During August and September, all upper river plains are drained and only the Paraguay-Nabileque remains flooded. At the end of the year, the Pantanal is dry again (Fig. 16) and the annual hydrologic cycle resets following the summer rainfall.

The water and sediment flows running over the irregular and rough surface of the floodplain develop erosive and depositional sites forming complex habitats. However, the original concept of moving littoral [58] is not applied in all areas of the Pantanal where the water enters the floodplain through different paths mainly through the anabranching channel systems, water body intercommunications, and the rising of the groundwater. Unlike the Amazon floodplain, in Pantanal the flooded areas may or may not exchange water with rivers [54]. Natural levees within floodplains work like dams because water only overpasses these levees at a certain water level threshold. Otherwise, small channel splits, temporarily or permanently connected to the mainstream, transfer the rising water to distant areas of the floodplain, before the rising river waters overpass the levees [53]. The Pantanal flood pulse is therefore distinct from the flood-pulse concept developed by Junk et al. [58] as a model for large Amazon rivers, in which the exchanges occur between the river and its surrounding floodplain. In the Amazon floodplain, the river is active and the floodplain receives and returns the water passively.

In the Pantanal, the river eventually loses water to the floodplain, and the water does not return to the river channel at the same river stretch but kilometers downstream. The relatively long time span of water damming into different floodplains of different provenance can affect water quality of the mainstem river in different moments of the hydrological year with strong influence on the Pantanal ecology and biogeochemistry. One of the well-known but still poorly studied phenomena related to water quality and ecology is regionally named "dequada" or "decoada" [59]. The phenomenon is associated to the return of floodplain water to the channel, which changes in water tranparency, $\mathrm{pH}$, electron conductivity, dissolved oxygen (DO) and carbon dioxide $\left(\mathrm{CO}_{2}\right)$ lead to fish mortality $[50,60]$. "Decoada" has also great relevance to greenhouse gas exchanges with the atmosphere, in particular methane $\left(\mathrm{CH}_{4}\right)$ and carbon dioxide $\left(\mathrm{CO}_{2}\right)$ [60]. The flood magnitude and "decoada" intensity show a direct relation measured by an intensity index for the "decoada" in the Paraguay River and its main tributaries [61].

\section{Conclusion}

Due to its morphology, drainage structure, and dynamics, the fans present very peculiar ways in transferring water and sediment to the mainstem river, with profound implications to flow regime, ecology, biodiversity, and local socioeconomy [63-65].

The narrow relation between the Pantanal ecology and its hydrological regime is well known [49, 61, 66, 67]. Water and sediment loads (dissolved, suspended, and 
bed loads) are very important not only for the floodplain morphogenesis and system maintenance, but on recycling nutrients to the biota. In this case, the action of the flood pulse [58], with variables as frequency, recurrence, intensity, tension, and permanence, over sites of different morphology has a relationship (connectivity in the concept of [68]) with the riparian vegetation and other ecological variables [69].

This chapter also highlights that avulsions and bottlenecks largely dictate the hydrodynamics and the ecohydrology of the Pantanal wetland. On the other hand, land-use changes (deforestation) in the highlands [31, 41, 70] necessarily need to be reverted (reforestation and livestock-agroforestry systems; see [32]) to likely decelerate the actual sediment load rate. By reintroducing tree elements in the Pantanal headwater landscape, besides to recover important ecosystem services as evapotranspiration and carbon storage [40], it is likely to reduce the rate of an eventual "anthropogenic accelerated avulsions" into the plains that ultimately can reduce ecosystems' resilience and make it difficult to promote the sustainable development in the lowlands. This issue is particularly important considering the possible climate change scenarios for the region [12].

The fluvial "avulsive and bottleneck" dynamics seasonally affects both local and regional ecohydrological processes, such as flora (and consequently fauna) distribution [42], tree biomass allocation [42], as well as biogeochemistry dynamics in floodplains and lakes [46, 60]. Moreover, it shows that avulsive processes are commonplace in Pantanal, and changes in land use, particularly in river headwaters in the highlands $[44,45]$, can accelerate the avulsions, making difficult a sustainable use of the Pantanal lowlands.

Acknowledgments The authors thank the São Paulo Research Foundation (FAPESP 2014/ 06889-2) and FUNDECT/CNPQ (23/200.628/2012) for financial support to our research in the Pantanal Basin, the National Council of Technological and Scientific Development (CNPq) for grants to MLA (308563/2013-1) and to AS (312386/2014-1), Fernanda Quaglio for helpful suggestions to improve the manuscript, and Patrícia Colombo Mescolotti for assistance in the preparation of figures.

\section{References}

1. Hamilton SK, Sippel SJ, Melack JM (2002) Comparison of inundation patterns among major South American floodplains. J Geophys Res 107(D20):8038

2. Nobre P, Shukla J (1996) Variations of sea surface temperature, wind stress, and rainfall over the tropical Atlantic and South America. J Clim 9:2464-2479

3. Lenters JD, Cook KH (1999) Summertime precipitation variability over South America: role of the large-scale circulation. Monthly Weather Rev 127:409-431

4. Thompson LG, Mosley-Thompson E, Henderson KA (2000) Ice-core palaeoclimate records in tropical South America since the Last Glacial Maximum. J Quat Sci 15:377-394

5. Marengo JA, Liebmann B, Kousky VE, Filizola NP, Wainer IC (2001) Onset and end of the rainy season in the Brazilian Amazon Basin. J Clim 14:833-852

6. Balek J (1983) Hydrology and water resources in tropical regions. Elsevier, Amsterdam 
7. Liebmann B, Camargo SJ, Seth A, Marengo JA, Carvalho LMV, Allured D, Fu R, Vera CS (2007) Onset and end of the rainy season in South America in observations and the ECHAM 4.5 Atmospheric General Circulation Model. J Clim 20:2037-2050

8. Zhou J, Lau K-M (1998) Does a monsoon climate exist over South America? J Clim 11:1020-1040

9. Vera C, Higgins W, Amador J, Ambrizzi T, Garreaud R, Gochis D, Gutzler D, Lettenmaier D, Marengo J, Mechoso C, Nogués-Paegle J, Silva Dias PLC (2006) Zhang toward a unified view of the American Monsoon Systems. J Clim 19:4977-5000

10. Garcia EAC (1984) O clima no Pantanal Mato-grossense, vol Circular técnica 14. EMBRAPAUEPAE Corumba

11. McGregor GR, Nieuwolt S (1998) Tropical climatology: an introduction to the climates of the low latitudes. 2nd edn. John Wiley and Sons, Chicester, England

12. Marengo J, Sampaio G, Alves LM (2015) Climate change scenarios in the Pantanal. Hdb Env Chem. doi:10.1007/698_2015_357

13. Krepper CM, García NO, Jones PD (2006) Paraguay river basin response to seasonal rainfall. Int J Climatol 26(9):1267-1278

14. Valeriano MM, Salvi LL, Aragão JRL Relações entre a distribuição da precipitação e o relevo da bacia do alto Paraguai. In: $4^{\circ}$ Simpósio de Geotecnologias no Pantanal, Bonito, MS, 2012. Anais. Embrapa Informática Agropecuária/INPE, pp 289-298

15. Assine ML, Merino ER, Pupim FN, Warren LV, Guerreiro R, McGlue MM (2015) Geology and geomorphology of the Pantanal basin. Hdb Env Chem. doi:10.1007/698_2015_349

16. Richards K, Chandra S, Friend PF (1993) Avulsive channel systems: characteristics and examples. In: Best JL, Bristow CS (eds) Braided rivers. Special Publication 75. Geological Society, London, pp 195-203

17. Leier AL, DeCelles PG, Pelletier JD (2005) Mountains, monsoons, and megafans. Geology 33 (4):289-292

18. Gole CV, Chitale SV (1966) Inland delta building activity of the Kosi River. J Hidraul Div 92:111-126

19. Stanistreet IG, McCarthy TS (1993) The Okavango Fan and the classification of subaerial fan systems. Sediment Geol 85(1-4):115-133

20. Weissmann GS, Hartley AJ, Nichols GJ, Scuderi LA, Olson M, Buehler H, Banteah R (2010) Fluvial form in modern continental sedimentary basins: distributive fluvial systems. Geology 38(1):39-42

21. Hartley AJ, Weissmann GS, Nichols GJ, Warwick GL (2010) Large distributive fluvial systems: characteristics, distribution, and controls on development. J Sediment Res 80:167-183

22. Braun EWG (1977) Cone aluvial do Taquari, unidade geomórfica marcante da planície quaternária do Pantanal. Revista Brasileira Geografia 39(4):164-180

23. Assine ML (2003) Sedimentação na Bacia do Pantanal Mato-Grossense, Centro-Oeste do Brasil. Tese de Livre-Docência, Universidade Estadual Paulista - Unesp, Rio Claro

24. Assine ML, Soares PC (2004) Quaternary of the Pantanal, west-central Brazil. Quat Int 114 (1):23-34

25. Assine ML (2005) River avulsions on the Taquari megafan, Pantanal wetland, Brazil. Geomorphology 70(3-4):357-371

26. Assine ML, Padovani CR, Zacharias AA, Angulo RJ, Souza MC (2005) Compartimentação geomorfológica, processos de avulsão fluvial e mudanças de curso do Rio Taquari, Pantanal Mato-Grossense. Revista Brasileira Geomorfologia 6(1):97-108

27. Buehler HA, Weissmann GS, Scuderi LA, Hartley AJ (2011) Spatial and temporal evolution of an avulsion on the Taquari river distributive fluvial system from satellite image analysis. J Sediment Res 81:630-640

28. Zani H, Assine ML, McGlue MM (2012) Remote sensing analysis of depositional landforms in alluvial settings: method development and application to the Taquari megafan, Pantanal (Brazil). Geomorphology 161-162:82-92 
29. Jones LS, Schumm SA (1999) Causes of avulsion: an overview. In: Smith ND, Rogers J (eds) Fluvial sedimentology VI. Blackwell Science, Oxford, UK, pp 171-178

30. Makaske B, Maathuis BHP, Padovani CR, Stolker C, Mosselman E, Jongman RHG (2012) Upstream and downstream controls of recent avulsions on the Taquari megafan, Pantanal, south-western Brazil. Earth Surf Process Landf 37(12):1313-1326

31. Galdino S, Vieira LM, Pellegrin LA (2006) Impactos ambientais e socioeconômicos na Bacia do Rio Taquari - Pantanal, 1st edn. Embrapa Pantanal, Corumbá

32. Bergier I (2013) Effects of highland land-use over lowlands of the Brazilian Pantanal. Sci Total Environ 463-464:1060-1066

33. Assine ML, Corradini FA, Pupim FN, McGlue MM (2014) Channel arrangements and depositional styles in the São Lourenço fluvial megafan, Brazilian Pantanal wetland. Sediment Geol 301:172-184

34. Correia Filho V (1942) Cuiabá, afluente do Paraguai. Revista Brasileira de Geografia IV(1):320

35. Assine ML, Silva A (2009) Contrasting fluvial styles of the Paraguay River in the northwestern border of the Pantanal wetland, Brazil. Geomorphology 113(3-4):189-199

36. Pupim FN, Zaparoli FCM, Assine ML (2012) O megaleque fluvial do rio Cuiabá, Pantanal do Mato Grosso. In: $9^{\circ}$ Simpósio Nacional de Geomorfologia, Rio de Janeiro

37. Carling P, Jansen J, Meshkova L (2014) Multichannel rivers: their definition and classification. Earth Surf Process Landf 39(1):26-37

38. Bravo J, Allasia D, Paz AR, Collischonn W, Tucci EM (2012) Coupled hydrologic-hydraulic modeling of the Upper Paraguay River Basin. J Hydrol Eng 17(5):635-646

39. Collischonn W, Tucci CEM, Clarke RT (2001) Further evidence of changes in the hydrological regime of the River Paraguay: part of a wider phenomenon of climate change? J Hydrol 245(1-4):218-238. doi:10.1016/s0022-1694(01)00348-1

40. D'Odorico P, Laio F, Porporato A, Ridolfi L, Rinaldo A, Rodriguez-Iturbe I (2010) Ecohydrology of terrestrial ecosystems. Bioscience 60(11):898-907. doi:10.1525/bio.2010. 60.11 .6

41. Silva JSV, Abdon MM, Silva SMA, Moraes JA (2011) Evolution of deforestation in the Brazilian Pantanal and surroundings in the timeframe 1976-2008. Geografia (Rio Claro) 36 (Especial):35-55

42. Pott A, Silva JSV (2015) Terrestrial and aquatic vegetation diversity of the Pantanal wetland. Hdb Env Chem. doi:10.1007/698_2015_352

43. Bergier I, Salis SM, Mattos PP (2015) Metabolic scaling applied to native woody savanna species in the Pantanal of Nhecolândia. Hdb Env Chem. doi:10.1007/698_2015_354

44. Dores E (2015) Pesticides in the Pantanal. Hdb Env Chem. doi:10.1007/698_2015_356

45. Buller LS, Silva GB, Zanetti MR, Ortega E, Moraes A, Goulart T, Bergier I (2015) Historical land-use changes in São Gabriel do Oeste at the Upper Taquari River basin. Hdb Env Chem. doi:10.1007/698_2015_355

46. Bergier I, Krusche A, Guérin F (2015) Alkaline lakes dynamics in the Nhecolândia landscape. Hdb Env Chem. doi:10.1007/698_2014_327

47. Franco MSM, Pinheiro R (1982) Geomorfologia. In: Brasil (ed) Ministério das Minas e Energia. Secretaria Geral. Projeto RADAMBRASIL. Folha SE.21 Corumbá e parte da Folha SE.2 (Levantamento de Recursos Naturais, 27). MME/SG/RADAMBRASIL, Rio de Janeiro, pp 161-224

48. ANA/GEF/PNUMA/OEA (2005) Modelo de Simulação Hidrológica do Alto Paraguai. Projeto Implementação de Práticas de Gerenciamento Integrado de Bacia Hidrográfica para o Pantanal e Bacia do Alto Paraguai. Subprojeto 5.4 - Modelo Integrado de Gerenciamento Hidrológico da Bacia do Alto Paraguai. Agência Nacional de Águas, Fundo para o Meio Ambiente Mundial, Programa das Nações Unidas para o Meio Ambiente, Organização dos Estados Americanos, $333 \mathrm{pp}$

49. Macedo HA, Assine ML, Pupim FN, Merino ER, Stevaux JC, Silva A (2014) Mudanças paleohidrológicas na planície do rio Paraguai, Quaternario do Pantanal. Revista Brasileira de Geomorfologia 15:75-85 
50. Kuerten S, Assine ML (2011) O rio Paraguai no megaleque do Nabileque, sudoeste do Pantanal Mato-Grossense, MS. Rev Bras Geosci 41(4):642-653

51. Kuerten S, Parolin M, Assine ML, McGlue MM (2013) Sponge spicules indicate Holocene environmental changes on the Nabileque River floodplain, southern Pantanal, Brazil. J Paleolimnol 49(2):171-183

52. Hamilton SK, Sippel SJ, Melack JM (1996) Inundation patterns in the Pantanal wetland of South America determined from passive microwave remote sensing. Arch Hydrobiol 137 (1): $1-23$

53. Padovani CR, Vettorazzi CA, Shimabukuro YE, Adami M, Freitas RM (2009) Estudo das inundações do Pantanal a partir de imagens MODIS. In: $14^{\circ}$ Simposio Brasileiro de Sensoriamento Remoto, Natal, Anais. INPE, pp 1-8

54. Padovani CR (2010) Dinâmica das Inundações do Pantanal. Universidade de São Paulo/ ESALQ, Piracicaba

55. Prass TS, Bravo JM, Clarke RT, Collischonn W, Lopes SRC (2012) Comparison of forecasts of mean monthly water level in the Paraguay River, Brazil, from two fractionally differenced models. Water Resour Res 48(5), W05502

56. Paz AR, Collischonn W, Bravo JM, Bates PD, Baugh C (2014) The influence of vertical water balance on modelling Pantanal (Brazil) spatio-temporal inundation dynamics. Hydrol Process 28(10):3539-3553

57. Cavazzana GH, Lastoria G, Roche KF, Catalini TGT, Paranhos Filho AC (2015) Natural and environmental vulnerability along the touristic "Estradas Parque Pantanal" by GIS algebraic mapping. Hdb Env Chem. doi:10.1007/698_2014_328

58. Junk JW, Bayley PB, Sparks RE (1989) The flood pulse concept in river floodplain systems. Can Spec Publ Fish Aquat Sci 106:110-127

59. Andrade MHS (2011) O fenômeno da "decoada" no Pantanal do rio Paraguay, Corumba, MS: alteração dos parâmetros limnológicos e o efeito sobre os organismos macroinvertebrados bentônicos. Doctoral Thesis, Universidade de São Paulo, São Paulo

60. Bergier I, Silva APS, Monteiro H, Guérin F, Macedo HA, Silva A, Krusche A, Sawakuchi HO, Bastviken D (2015) Methane and carbon dioxide emissions from the Paraguay River floodplain (Pantanal) during episodic anoxia events. Hdb Env Chem. doi:10.1007/698_2015_353

61. Macedo HA, Stevaux JC, Silva A, Merino ER, Pupim FN, Bergier I Distribuição e classificação da intensidade do fenômeno de dequada no Pantanal. In: $5^{\circ}$ Simpósio de Geotecnologias do Pantanal, Campo Grande, MS, 2014b. Anais. Embrapa/INPE, pp 720-730

62. Oliveira MD, Calheiros DF, Padovani CR (2013) Mapeamento e Descrição das Áreas de Ocorrência dos Eventos de Decoada no Pantanal. Boletim de Pesquisa e Desenvolvimento / Embrapa Pantanal, Corumbá-MS, 21 pp

63. Alho CJR (2008) Biodiversity of the Pantanal: response to seasonal flooding regime and to environmental degradation. Braz J Biol 68:957-966

64. Mamede S, Alho CJR (2006) Response of wild mammals to seasonal shrinking-and-expansion of habitats due to flooding regime of the Pantanal, Brazil. Braz J Biol 66(4):991-998

65. Schulz C, Ioris AA, Martin-Ortega J, Glenk K (2014) Prospects for payments for ecosystem services in the Brazilian Pantanal: a scenario analysis. J Environ Dev 1070496514548580

66. Mittermeier RA, de Gusmao CI, Pádua MTJ, Blanck J (1990) Conservation in the Pantanal of Brazil. Oryx 24(02):103-112

67. Resende EK (2008) Pulso de inundação: processo ecológico essencial à vida no Pantanal. Documentos 34. Embrapa, Corumbá

68. Stevaux JC, Corradini FA, Aquino S (2013) Connectivity processes and riparian vegetation of the upper Paraná River, Brazil. J S Am Earth Sci 46:113-121

69. Neiff JJ, Poi de Neiff ASG (2003) Connectivity processes as a basis for the management of aquatic plants. In: Thomaz SM, Bini LM (eds) Ecologia e Manejo de Macrófitas Aquáticas. Editora UEM, Maringa, pp 39-58

70. Embrapa Pantanal; WWF - Brasil (2014) Monitoramento das alterações da cobertura vegetal e uso da terra na bacia do alto rio Paraguai: Porção Brasileira: período de analise: 2010 to 2012. Brasília, 73 pp 